\title{
Operating Leverage and Stock Returns: International Evidence
}

\author{
Luis García-Feijóo \\ College of Business \\ Florida Atlantic University \\ Benjamin A. Jansen ${ }^{1}$ \\ Jones College of Business \\ Middle Tennessee State University
}

$1 / 27 / 2020$

\begin{abstract}
We empirically test theories predicting the association of operating leverage with stock returns and the value premium using an international data sample. Results suggest that operating leverage is related to stock returns and the value premium across the sampled countries. Results are robust to cross-country differences, typical controls, multiple definitions of operating and financial leverage, and while controlling for the endogeneity of operating and financial leverage. This suggests that the explanation for the presence of the value premium lies in the underlying risk exposure of fixed asset risk of operating leverage which is expressed through the value premium. Results further suggest that strengthening labor protection exogenously increases operating leverage.
\end{abstract}

\footnotetext{
${ }^{1}$ Correspondence information: Benjamin.Jansen@mtsu.edu, Middle Tennessee State University, Murfreesboro, Tennessee. We would like to thank helpful comments from Anne Anderson, Scott Barnhart, and David Javakhadze, and conference participants at the 2017 Financial Management Association's Doctoral Consortium.
} 


\section{Introduction}

Research suggests that operating leverage (OL) is a fundamental determinant of stock returns (Rubinstein (1973) and Lev (1974)). Additionally, recent theoretical and empirical studies have found evidence suggesting that OL is the underlying risk factor inducing the value premium (Garcia-Feijoo \& Jorgensen (2010), Novy-Marx (2011) and Gulen et al. (2011)), but there has been conflicting predictions and empirical findings (Ozdagli (2012), Choi (2013) and Cao (2015)). However, research studying the empirical association of OL with stock returns and the value premium is scarce, especially in an international context. Furthermore, the existing literature investigating OL's association with stock returns and the value premium do not control for the endogeneity between OL and financial leverage (FL, Chen et al. (2016)). Additionally, sample sizes and time periods have been relatively small, and there is heterogeneity in the proxies used for OL. This cumulatively suggests that there is need for further empirical tests associating OL with stock returns and the value premium.

We address the shortcomings of existing literature by providing a broad international investigation of OL's association with stock returns and the value premium, while controlling for the endogeneity between OL and FL, and using the largest set of OL proxies to test the hypotheses. We further extend the literature by taking advantage of differences in cross-country labor-restrictiveness, which theory predicts would affect OL. Through investigating the role of operating leverage in stock returns and the value premium, this paper extends our understanding of factors through which systematic risk exposure is generated and which expected returns are conditioned upon. Operating leverage is a particularly interesting potential return factor to investigate because of the theories suggesting its association with stock returns and riskiness and because there is relatively little empirical evidence testing these theories. 
Much of stock pricing literature has focused on anomalies (variables which explain stock return contrary to classical theoretical models) which may explain stock returns. Prominent anomalies include: size (Banz (1981), and Fama \& French (1992, 1993, 1996)), reversal (DeBondt \& Thaler (1985), and Bremer \& Sweeney (1991)), momentum (Jegadeesh \& Titman (1993, 2001)), profitability (Basu (1977, 1983), Fama \& French (2008) and Novy-Marx (2013)), and book-to-market, or the value premium (Stattman (1980), Rosenberg et al. (1985), and Fama \& French $(1992,1993,1996))$. Each of these variables has been independently, and in many cases jointly, shown to have explanatory power in stock returns and significant return implications for investors who follow the implied strategy of the anomaly. One of the most prominent anomalies, both economically and statistically, to date is the value premium.

Prior studies have found evidence which suggests that operating leverage is theoretically and empirically the cause of the value premium found in stock returns. However, these studies, such as Garcia-Feijoo \& Jorgensen (2010), Novy-Marx (2011), Gulen et al. (2011), Ozdagli (2012), Choi (2013) and Cao (2015), are limited in their implications because of their focus on domestic data, small sample periods, and have heterogenous OL proxies. This paper tests these findings in an international setting, thereby extending the implications of the value and operating leverage findings to broader market participants.

Results suggest that the Chen et al. (2016), Novy-Marx (2011), and degree of operating leverage (DOL) measures of operating leverage (OL) are significantly positively related to stock returns. Additionally, data suggests that book financial leverage (BFL) is significantly negatively related to stock returns across all subsamples, and market financial leverage (MFL) is significantly positive across all subsamples. Results further suggest that leverage is associated with the value premium. The value premium is negatively associated with COL and NOL, 
however it is positively related to DOL and FL. The negative association between the value premium with COL and NOL is likely a reflection of the mechanical measure of these variables. While the sign of the relationship is conditional on the empirical measure of leverage, results suggest that, overall, leverage is significantly associated with stock returns and the value premium.

The contribution of this paper lies in its empirical tests of the theories of Rubinstein (1973), Lev (1974), Mandelker \& Rhee (1984), and Carlson et al. (2004), which predict a positive association between OL with stock returns and the value premium. We extend the work of Novy-Narx (2011), Garcia-Feijoo \& Jorgensen (2010) and Gulen et al. (2011) by being the first empirical study to test the association of OL with stock returns and the value premium in an international sample, and by explicitly controlling for the endogeneity between OL and FL. This extension is significant because recent work, Ozdagli (2012), Hackbarth \& Johnson (2015), and Cao (2015), find evidence incongruous with the theory and empirical findings, and it is a matter of empirical investigation to test which group of theories and findings supports the data.

The paper proceeds as follows. Section 2 reviews the literature and develops the hypotheses; Section 3 discusses the data and presents summary statistics; Section 4 presents results testing the association between OL and stock returns; Section 5 presents results testing the association between OL and the value premium; Section 6 presents results testing the association of cross-country employment protection on OL; Section 7 concludes.

\section{Literature Review \& Hypothesis Development}

\subsection{Operating Leverage}

Leverage is the use of fixed costs to increase profitability potential. However, along with the increase in profitability potential, there is a significant increase in risk because leverage 
simultaneously exaggerates any potential loss a firm may incur. The increase in profitability potential in using leverage stems from extracting more output from a constant input. If a firm expects that it may be able to increase output with a constant input, then the firm will end up more profitable. If, however, the firm is not actually capable of increasing profit, or rather the fix cost is a less efficient means of production, then the leverage will result in a fixed cost to the firm without the ensuing profits to cover these costs and thereby exaggerating losses.

OL research was motivated by identifying the sources of systematic risk exposure after the development of the CAPM. Rubinstein (1973) establishes a model which expresses a positive relationship between OL, FL and stock return. He accomplishes this by rearranging a CAPMlike model relating systematic risk exposure to stock return to explicitly show the underpinning types of risk captured in systematic risk, particularly OL and FL. Lev (1974) develops a model which shows that a firm's DOL may be used to increase the firm's idiosyncratic and systematic risk exposure. Lev empirically verifies this model by showing a positive association between a firm's OL and risk exposure. However, Lev's sample is small and he notes that OL alone cannot entirely explain risk exposure. Mandelker \& Rhee (1984) theoretically show and empirically find that a firm's OL and FL is significantly positively related to a firm's beta. Huffman (1989) empirically continues Mandelker \& Rhee's study, but he finds that FL is positively related to systematic risk, while OL is negatively related to systematic risk and that OL and FL are negatively related. Booth (1990) develops a production model which expresses a firm's risk and aggregate cost of capital as related to a firm's fixed production costs. He shows that the capitallabor ratio is negatively related to returns and risk exposure, while DOL is negatively related to the capital-labor ratio, indicating that DOL should ultimately be positively related to stock returns and systematic risk. 
Kahl et al. (2014) discuss how endogeneity exists between the firm's two types of leverage and present empirical evidence of the relationship between OL and a firm's financing policy. When considering what sort of operating cost structure to use, firms must consider the cost structure of their capital, and vice versa. This results in a significantly negative association between OL and FL, which indicates that firms make a tradeoff decision between operating and financial leverage. Lambrecht et al. (2016) develop a real option model which expresses a firm's beta as a positive function in the firm's OL under different production conditions. Furthermore, they note how a firm's capital and production decisions are endogenously generated, which merits further investigation. Chen et al. (2016) find that OL is positively related to profitability, and that this association and the endogenous relation between OL and FL induces a negative relationship between FL and profitability. These studies find convincing evidence suggesting an endogenous relationship between OL and FL, however, as discussed below, studies relating OL to stock returns and the value premium have not controlled for this endogeneity.

A recent strand of literature has shown evidence which suggests that labor costs, such as compensation and unionization, play a role in the firm's operating leverage and risk exposure. Ruback \& Zimmerman (1984) find evidence which suggests that labor unions reduce a firm's profitability and market value. Rosett (2001) finds that a firm's labor costs are significantly related to its risk exposure, and better explains the exposure than does OL or FL. Danthine \& Donaldson (2002) develop a model which shows a positive relation between a firm's OL and stock return, which jointly shows the relatively fixed cost of compensation in some firms as being a component of OL. Motivated by the difficulty in empirically measuring a firm's operating flexibility and showing that labor unions are a significant subset of a firm's OL, Chen et al. (2011) find that the presence of labor unions increase a firm's OL and cost of equity. 
Furthermore, Simintzi et al. (2014) find international evidence that labor protection decreases FL. They interpret this result as meaning that EPL increases OL, and because of the tradeoff between OL and FL, therefore EPL decreases FL. However, they do not directly test the association of EPL and OL. This further suggests a tradeoff between OL and FL, and supports the concern for the relationship inherent between a firm's OL and its FL.

\subsection{Operating Leverage \& Value Premium}

The value premium was originally found by Stattman (1980) and Rosenberg et al. (1985), whose results suggest that stock returns are positively related to the value of book equity to the value of market equity. This suggests that investors who focus their investment into firms with relatively higher B/M ratios may be able to earn substantially higher risk adjusted returns. Fama \& French $(1992,1993)$ find evidence that Book-to-Market Equity (B/M) and size offer the highest joint explanatory power in stock returns, and additionally find that after controlling for these variables that beta does not offer much explanatory power. Fama \& French (2012) find that the value premium exists across countries, and Asness et al. (2013) find evidence suggesting that the value premium is present both across countries and across asset classes. This cumulatively suggests that the value premium may be an inherent risk premium paid to shareholders and which must be controlled for in stock return models.

The value premium was initially a purely empirical finding, which motivated researchers to develop theory explaining why B/M should be significant in stock returns. Carlson et al. (2004) express a model whereby B/M effects are directly reflective of a firm's operating leverage. Their model decomposes a firm's beta and show that it is made up of the riskiness of unlevered assets in place, leverage from growth options, and operating leverage. They note that firm risk of OL is similar to financial leverage, but is driven by physical rather than financial capital. Zhang (2005) develops a model which suggests that assets in place are riskier than 
growth options, and therefore firms with higher $\mathrm{B} / \mathrm{M}$ are more exposed to downturns. This risk in firms with high $\mathrm{B} / \mathrm{M}$ comes from having more assets in place, as compared to growth firms. When these firms face economically difficult times, value firms are not as able to reduce their capital stocks and are left holding unprofitable capital, whereas growth firms merely have to not exercise their growth options. Penman et al. (2007) find evidence suggesting that OL is positively related to stock returns and the value premium, while FL is negatively related to stock returns when controlling for OL. Novy-Marx (2011) theoretically and empirically establishes the direct relationship between OL and stock returns and the role OL has in explaining the presence of the value premium. Results suggest that stock return is significantly positively related to OL, and further imply that OL explains the value premium which prior studies have found, in line with what financial theory predicts.

Garcia-Feijoo \& Jorgensen (2010) test the empirical implications of the theories developed by Lev (1974), Mandelker \& Rhee (1984) and Carlson et al. (2004) predicting that the relation of OL with stock returns and the value premium. Their results suggest that DOL is positively related to stock returns and the value premium, and that DOL is positively related to systematic risk, which suggests that $\mathrm{OL}$ is a priced risk factor and the value premium is merely reflective of this priced risk. Gulen et al. (2011) find that value firms have higher OL and other measures of inflexibility, further indicating that the inflexibility of the firms' structure necessitates a risk premium on its stock return, which is captured through the firm's relatively higher B/M value. Guthrie (2011) extends prior theories by showing that the explicit inclusion of real options in the firm's activities, OL is positively related to stock returns when OL is low, but OL is negatively related to stock returns when OL is high. This result comes from the ability of 
firms to abandon highly unprofitable projects. This suggests that OL has a concave relationship with stock returns.

Several recent papers have been developed which suggest a different relationship between OL and stock returns compared to the standard models and findings in the field. Ozdagli (2012) develops a model which suggests that FL is the driver of the risk premium found in value stocks rather than OL. This is specifically contrary to the findings of Penman et al. (2007), and more generally contrary to the findings of other research. However, Ozdagli does not control for the inherent relationship between OL and FL which may adversely result in biased empirical tests. Similar to Guthrie (2011), Hackbarth \& Johnson (2015) develop a model incorporating real options in stock returns and predict that the real option effect subsumes the OL effect. They show that when profitability increases, OL reduces risk because the firm will ultimately be more profitable from the leverage. While when profitability increases, real options increase riskiness because firms are more likely to exercise their call option, which exposes the firm to increased productivity risk. In line with the predictions of Ozdagli and Hackbarth \& Johnson, Cao (2015) finds that $\mathrm{OL}$ is insignificant in the value premium, and that $\mathrm{OL}$ is negatively related to future stock returns. Cao finds evidence suggesting that FL, rather than OL, drives the value premium and is positively associated with stock returns. A significant issue in the empirical implementation of these papers is that they do not address the endogeneity inherent to OL and FL. Not controlling for this may lead to incorrect conclusions from the data.

\subsection{Operating Leverage in an International Setting}

The research to-date investigating the association of OL with stock returns and the value premium has been conducted domestically, leaving room for an investigation into how the association will be affected by cross-country differences. Domestic research has found a positive 
association of employment protection and OL and the cost of equity. Additionally, research finds evidence for a negative association Employment Protection Legislation (EPL) and FL, and the theoretical channel of this relationship through EPL's association with OL, however a direct test of this association is not conducted.

Chen et al. (2011) find evidence suggesting that unionization is positively associated with OL and the cost of equity is significantly higher for firms operating in more unionized industries. The positive association between unions and OL stems from the fact that a significant component of a firm's operating costs are labor costs, therefore, any factor which increases the bargaining power of labor will increase the cost of labor and therefore increase OL.

Simintzi et al. (2014) find evidence which suggests that countries which have stronger labor protection are negatively associated with FL. They argue that the channel for this relationship stems from the trade-off of OL and FL, and EPL being positively associated with OL. However, they do not directly test the association of EPL and OL. Counterfactually, Simintzi et al. (2014) findings imply that firms operating in countries with stronger labor protection laws will have higher OL compared to firms in countries with weaker labor protection laws, and that OL will make up more of the leverage premium because OL has crowded out FL in stock returns. Similarly, because Chen et al. (2011) find that unionization, which is a specific form of labor protection, is positively associated with the cost of equity, firm's operating in countries with stronger labor protection should have higher average stock returns than firm's operating in countries with weaker labor protection. Furthermore, Woods et al. (2017) find empirical evidence suggesting that higher labor unions crowd out FL, given labor is a significant component of OL, this finding supports the crowding out hypothesis of OL in countries with higher labor protection. 


\subsection{Hypotheses}

Because there are different findings and implications in the theories and domestic tests relating $\mathrm{OL}, \mathrm{B} / \mathrm{M}$, and stock returns, using a larger international dataset may help affirm the predictions and findings of a particular theory. Which theory is supported by the data is a matter of empirical investigation.

\section{Operating Leverage and Stock Return}

Consistent with the theories and domestic empirical findings of the relationship between OL and stock returns (Lev (1974), Mandelker \& Rhee (1984), Carlson et al. (2004), Novy-Narx (2011), Garcia-Feijoo \& Jorgensen (2010) and Gulen et al. (2011)), we hypothesize that OL will be positively related to stock returns. This association may hold while controlling for FL, but furthermore the association between OL and stock returns should be best measured when controlling for the endogeneity between OL and FL.

Consistent with the theories and domestic empirical findings of the relationship between OL and the value premium (Carlson et al. (2004), Novy-Narx (2011), Garcia-Feijoo \& Jorgensen (2010) and Gulen et al. (2011)), we hypothesize that OL will be positively associated with the value. Furthermore, this association should be positive once controlling for FL and the endogeneity between OL and FL.

The theories of Carlson et al. (2004) and Novy-Narx (2011) further predict that it is OL which exclusively explains the value premium, which precludes the relevance of FL in the value premium as predicted by Rubenstein (1973) and Choi (2013). Therefore, we hypothesize that it is OL, rather than FL which explains the value premium.

\section{Differences between Countries with and without Strong Labor Protection}

Kahl et al. (2014), Chen et al. (2016) and Woods et al. (2017) present evidence suggesting that OL and FL are jointly determined, and therefore any analysis including OL will 
simultaneously capture the effect of FL. International data offer an exogenous shock which may affect OL. In countries with stronger labor protection, Simintzi et al. (2014) and Woods et al. (2017) posit that firms are forced into higher OL positions, which crowds out FL. Therefore, we hypothesize that in countries with stronger labor protection, firms will have higher OL.

\section{Data}

\subsection{Data}

Data are gathered from Datastream-Worldscope from 1980 through 2016 for profitable firms from OCED countries with stock prices greater than $\$ 1$, following Chen et al. (2016). Although not tabulated, results are repeated including the unprofitable firms with an indicator variable specifying unprofitability for a firm in a given year and results are similar to those shown below. Datastream-Worldscope reports the return index, from which the return is calculated. Following Ince \& Porter (2006), firms are screened for large reversals, dropped if the firm does not have more than twelve continuous monthly observations, countries are dropped if they do not have at least thirty firms. This results in gathering data for 18,732 unique firms from 20 countries. All tests discussed below will be additionally run within each country to see whether there is a difference across countries with the role of OL. Unless otherwise mentioned, all independent variables are updated each June for each firm so that there is a 4 to 6 month gap between financial reporting in order to ensure that investors have publicly available information. In order to account for cross-country differences, we follow McLean et al. (2009) and Watanabe et al. (2013) in running regressions with country fixed effects and running regressions within each country.

OL is measured in two ways. Following Chen et al. (2016), OL is measured as selling, general and administrative plus (SGA) over total assets (TA); this OL measure will be denoted as COL. To conserve space we do not tabulate results using Novy-Marx (2011) OL measure as the 
sum of SGA and the cost of goods sold (COGS) divided by total assets because it is highly correlated with NOL. Following Mandelker \& Rhee (1984), O’Brien \& Vanderheiden (1987), and Garcia-Feijoo \& Jorgensen (2010), DOL is taken as the time adjusted relation between operating cash flow growth and sales growth over 5-year windows for each firm. Specifically, the natural log of earnings before interest and taxes (EBIT) and sales are netted from their respective values prior to the start of the 5-year estimating window. These netted values are then regressed on a variable representing the relative time of each EBIT and sales within the estimation window. The residuals of these regressions are then used to estimate DOL, with DOL being the estimated coefficient regression of the residual of the EBIT regression on the residual from the sales regression. While empirical research has used COL to test hypotheses associated with OL, the theory established by Lev (1974), McDaniel (1983), Mandelker \& Rhee (1984), O'Brien \& Vanderheiden (1987) posit that DOL is the most empirically appropriate approximation of a firm's OL. Furthermore, there are several cross-country accounting differences which further tilt the practical use of DOL over COL and NOL. Specifically, under GAAP accounting guidelines, firms operating in the U.S. are allowed to use LIFO accounting, which artificially increases the accounting amount reported of operating costs until the cost is expensed. For example, if two firms, one in the U.S. the other listed in the U.K., have the same exact costs structure, however the U.S. listed firm uses LIFO. The U.S. will report a higher COGS and therefore have a higher COL than the U.K. firm despite the two firms having the same costs. Furthermore, firms operating internationally under the IFRS practices are allowed to expense R\&D costs over several years, which is reflected through COL. Similar to the above example, a firm in the U.K. may expense R\&D under its SGA over several years, whereas a firm in the U.S. would have to expense it immediately. However, because DOL is time detrended and 
is the relative responsiveness of operating income to changes in sales, cross-country accounting differences won't have such a drastic effect on the DOL estimate, as compared to the effect these accounting differences will have on COL. Furthermore, COL measure may partially reflect the firm's variable costs, rather than just measuring the firm's fixed cost. While Chen et al. (2016) argue their measure better reflects the firms fixed costs, SG\&A still reflects variable costs through including commissions, travel expenses, and other employee and advertising costs which vary with the sales amount.

Similarly, FL is measured using 2 definitions established in prior literature. Following Rajan \& Zingales (1995), Huizinga et al. (2008), Frank \& Goyal (2009), Ozdagli (2012), Hou et al. (2013) and Cao (2015), book financial leverage (BFL) is measured as debt (the sum of short and long-term debt) to total assets. Following Mandelker \& Rhee (1984), O’Brien \& Vanderheiden (1987), and Garcia-Feijoo \& Jorgensen (2010), we measure the degree of financial leverage (DFL) similar to DOL, however, we regress the residual of EBIT to net income to measure the elasticity of financial leverage. We also measure FL as market financial leverage (MFL) measured as one minus market value of equity scaled by the sum of market value of equity and total book assets minus the book value of equity and deferred taxes. An alternative market financial leverage measure is estimated following Rajan \& Zingales (1995), Huizinga et al. (2008), Frank \& Goyal (2009) and Simintzi et al. (2015), and is debt scaled by market value of equity. While the recent work by Cao (2015), which compares OL and FL in their role in the value premium, uses MFL financial research typically uses either BFL to measure a firms FL. Therefore, we only report results of BFL and DFL to conserve space.

Following Novy-Marx (2011), Garcia-Feijoo \& Jorgensen (2010), and Cao (2015) additional control variables for the return regressions include market capitalization (Size), the 
prior month's return (LRET), and the cumulative return from t-2 through t-12 (MOM). Book-tomarket equity $(\mathrm{BM})$ is the natural log of book-to-market equity, where in order to avoid contemporaneous correlations between equity measures, the market value in the denominator is taken from the last December rather than the last June. Because we run BM as a function of OL below, we run return regressions both with and without controlling for BM.

In the firm level BM regressions, we follow the control variables of Lemmon et al. (2008), Matsa (2010), and Marciukaityte (2015). Control variables for the BM regressions include the natural log of sales (Sales), tangibility measured as the firms fixed assets, Property, Plant and Equipment, scaled by total assets (Tang), profitability measured as net income over assets (NIA), and year fixed effects. Additionally: following Novy-Marx’s (2011) theory signaling industry effects present in the value premium, we control for industry fixed effects and following the theory of Carlson et al. (2004) in explaining the value and size premium, we control for sales risk measured as the 5-year rolling standard deviation of the firm's sales (Sales_SD).

We follow Novy-Marx (2011), Fama-French (2012), and Asness et al. (2013) in generating the Fama-French factors and controls. Specifically, each factor is measured within each country as either the equal or value weighted return of each tercile portfolio, and the difference of the top tercile from the bottom tercile is taken. These portfolios are rebalanced each June.

\subsection{Summary Statistics}

Table 1 Panel A presents the total number of firms per country and the percentage of total firms each country has relative to the full sample. Of the 18,732 unique firms in the total sample: $6,538(34 \%)$ are listed in the U.S.; 3,921 (20\%) are listed in Japan; 1,076 (6\%) are listed in 
France; 8,57 (5\%) are listed in Germany; 1,915 (10\%) are listed in the U.K.; and $853(5 \%)$ are listed in Canada. The remaining countries hold less than $3 \%$ of the total of sampled firms. The number of firms and distribution of observations are in line with other international studies, such as Hou et al. (2011) and Watanabe et al. (2013). Table 1 Panel B presents summary statistics per country and totaled average. Statistics are listed as the mean, standard deviation, and the firmmonth (year) observations, respectively. Despite the U.S. representing the most firms, Table 2 reflects the relative similarity of the variables across firms and between countries, with many of the countries reflecting averages similar to one another.

[Insert Table 1 here]

The distribution of sampled firms suggests that much of the analysis will be driven by the results obtained from data within the countries with the largest number of firms sampled. Because of the lack of even distribution of observations across countries, we investigate results using the aggregate sample, and split the sample into regions of North America, Europe, and Asia.

\section{Leverage and Stock Return}

\subsection{Univariate Sorts}

Table 2 presents univariate quintile sorts of equal-weighted average monthly stock returns across independent variables. OL and FL portfolios are created within each country and rebalanced each June. Returns are then averaged across portfolios within each date. In line with H1 and the findings of Garcia-Feijoo \& Jorgensen (2010), Novy-Marx (2011), and Cao (2015) the COL and DOL sorts show significant positive differences between the top and bottom quintile, monthly return differences of $0.15 \%, 0.2 \%$ and $0.2 \%$ respectively, indicating that $\mathrm{OL}$ is positively significant with stock returns. BFL shows a statistically significant and negative 
relation of difference of $-0.3 \%$ per month stock returns between the top and bottom quintile, while MFL shows a statistically and significantly positive difference of $0.6 \%$ per month between the top and bottom quintile. AMFL has an insignificant association in the univariate sorts. Additionally, the most statistically and economically significant difference comes from the MFL sorts, suggesting that financial, as opposed to operating, leverage may be the fixed cost structure of more priced relevance in stock returns. However, these sorts do not control for other variables, including cross-country differences. Results in Table 2 do not express support for $\mathrm{H} 2$, as there does not appear to be any concave association of stock returns within the sorts.

[Insert Table 2 here]

\subsection{Base Results}

Table 3 presents Fama-MacBeth regressions estimating monthly stock returns. The firm level controls follow Novy-Marx (2011), Garcia-Feijoo \& Jorgensen (2010), and Cao (2015) in controlling for BM, market capitalization, lagged return, and momentum. Furthermore, we follow McLean et al. (2009) and Watanabe et al. (2013) in controlling for cross-country heterogeneity through using country fixed effects, as well as following Fama \& French (2012) in running each regression within geographic region (North America, Europe, and Asia) reported below. Panel A is the full sample, Panel B is the North American sample, Panel C is the European sample, and Panel D is the Asian Sample. Within each panel, Column (1) presents regressions only controlling for country fixed effects, regressions (2)- (10) jointly test OL and FL and control for BM, size, lagged return, and momentum.

[Insert Table 3 here]

Results of Table 3 agree with the signs found in Table 2. In support of H1 and the findings of Garcia-Feijoo \& Jorgensen (2010) and Novy-Marx (2011), the OL measures COL, 
NOL and DOL are significantly positive. Although, the statistical dependence varies across sample and controls for OL, with its significance being strong in the full sample, North America, and Europe, and weak in Asia. BFL is statistically negatively significant in the aggregate sample, though statistical significance declines outside North America and when additionally controlling for other variables. MFL is statistically positively significant across all specifications and control inclusions, and maintains the highest relative significance throughout the regressions. AMFL is insignificant in the majority of specifications. Overall, these results suggest two things: 1) OL is positively related to stock returns, and 2) among the financial leverage proxies, MFL is positively related and appears to have the most statistical and economic relevance in stock returns.

Although not tabulated, we also use controls which are theoretically predicted to be jointly associated with OL (sales and sales risk), as well as excluding BM because BM is the dependent variable of interest in proceeding analysis, and results remain similar. Additionally tested is Guthrie's (2011) theory predicting a concave association between OL and stock returns, and results do not express support for the predicted concave association.

\subsection{Endogeneity Concerns}

Kahl et al. (2014), Chen et al. (2016) and Woods et al. (2017) develop the argument of the endogeneity of OL and FL, and while jointly controlling for each of these variables in tests which predict a relationship of one of these measures with another economic factor, further steps may be taken to alleviate endogeneity concerns of the above results. Table 4 presents FamaMacBeth regressions of orthogonalized measures of leverage. Specifically, each measure of OL is orthogonalized from the correspondingly controlled for measure of FL. Results Presented in Table 4 confirm the results found above, OL is positively related to stock returns, while BFL is 
negatively related to stock returns and MFL is positively related to stock returns. AMFL is marginally positively related to returns without controls, though with controls included it becomes significantly negatively related to returns.

[Insert Table 4 here]

\section{Leverage and the Value Premium}

\subsection{Univariate Sorts}

Table 5 presents univariate sorts of $\mathrm{BM}$ across the leverage measures for the aggregate, North America, European, and Asian samples. Contrary to the third hypothesis, BM is negatively associated with COL and NOL measures of OL. However, in line with the third hypothesis, DOL has a statistically significant and positive association with BM. BM has a significant and positive difference across BFL sorts, however most of this difference occurs after the $1^{\text {st }}$ quintile, after which $\mathrm{BM}$ is more similar across quintiles. BM has a highly significant and positive difference across MFL and AMFL sorts, and BM is most closely associated with MFL than any other leverage measure. These results suggest that both operating and financial leverage is significantly related to BM and therefore associated with the value premium, in line with the results of Garcia-Feijoo \& Jorgensen (2010), Novy-Marx (2011), and Cao (2015).

[Insert Table 5 here]

\subsection{OLS Regressions}

Table 6 presents annual OLS regressions estimating BM with leverage as the independent variable. We follow Marciukaityte (2015) in control variables for the firm level BM specification. Specifically, we control for sales (SALES), 5 year moving sales volatility (SALES_SD), net income scaled by assets (NIA), tangibility measured as property, plant, and equipment scaled by total assets (TANG), and industry-year-country fixed effects. Contrary to 
$\mathrm{H} 3, \mathrm{COL}$ is significantly and negatively related to BM. Consistent with $\mathrm{H} 3$ and the results of Garcia-Feijoo \& Jorgensen (2010), Novy-Marx (2011) and Gulen et al. (2011), NOL and DOL are significantly and positively related to BM. The results for COL make sense mechanically when considering that the denominator of the variables is the numerator of the dependent variable. Additionally, BFL is negatively related (though positively related in North America) to and MFL and AMFL are significantly and positively associated with BM, consistent with the evidence presented by Cao (2015). Of the tested measures of leverage, DOL and AMFL are the most statistically and economically significantly variable tested. Results suggest that both OL and FL have explanatory power for BM. One issue with the above specification is that OL is measured with error. In order to alleviate the errors in measurement of OL, Garcia-Feijoo \& Jorgensen (2010) use OL as the dependent variable in relation to BM so that the residual term captures the error in OL measurement. Although not tabulated, we additionally test the association of OL and BM with OL as the dependent variable and results remain similar.

\section{[Insert Table 6 here]}

\subsection{Orthogonalized Leverage Regressions}

The findings presented by Kahl et al. (2014) and Chen et al. (2016) suggest that there is a relationship between OL and FL, and prior studies testing OL and FL's association with the value premium have not taken into account the joint association of OL and FL with one another. Other than jointly controlling for both OL and FL, another method to disentangle the joint effect of OL and FL is to orthogonalize OL and FL to one another and test these orthogonalized leverage measures on BM. Table 7 presents annual OLS regressions estimating BM with orthogonalized leverage as the independent variable. Each measure of operating and financial leverage is orthogonalized to the simultaneously controlled for measure of leverage. 


\section{[Insert Table 7 here]}

Results show similar support to what is reported in Table 6, orthogonalized leverage measures do not appear to significantly alter their mutual effect on BM. This suggests that, conditional on the empirical measure of leverage, although OL and FL may be associated with one another, their joint determination and simultaneous association with the value premium do not significantly alter their association with the value premium.

\subsection{Fama-French Time-Series Value Premium Estimates}

Following Hou et al. (2011) and Asness et al. (2013), Table 8 presents estimates for Fama-French time-series regressions estimating the value premium. Each factor is measured as the difference of the return in the top tercile from the return in the bottom tercile. Each factor is estimated within each country and then the estimates are averaged across countries with country fixed effects. Contrary to the third hypothesis, the estimated coefficients of the COL and NOL factors are significantly negative, however, in line with the prediction of the third hypothesis, the estimated coefficient of the DOL factor is significantly positive. Furthermore, all the estimated coefficients of the FL factors are significantly positive, contrary to the fourth hypothesis, which predicts OL explains the value premium while FL does not.

[Insert Table 8 here]

Results presented in this section suggest that OL is associated with the value premium. However, evidence also suggests that FL is related to the value premium as well. While results suggest that the joint determination of OL and FL do not significantly alter the estimates, international data allows for further investigation for separating out the OL effect from FL in the value premium. Countries cross-sectionally differ in labor protection, which is a significant 
component of OL, therefore using cross-country difference in labor protection offers another test for the effect of OL on the value premium, exogenously from the financial structure of the firm.

\section{Employment Protection Effect on Operating Leverage}

While papers such as Simintzi et al. (2014) and Woods et al. (2017) assume that OL is the underlying mechanism for the inverse association of EPL and FL, they do not directly test EPL effects on OL. We extend these papers by first providing evidence that EPL increases OL and then test the hypothesis whether EPL shocks the value premium. Following Dessaint et al. (2017), we use a difference-in-differences analysis in testing the effect of EPL on OL. Where the treatment, EPL -/+ $\mathrm{i}$ is a dummy equal to 1 if the year of the deal is the ith year before (after) the employment reform and zero otherwise, is used to test whether exogenous legislation significantly increases a firm's OL. Results are tabulated in Table 9. Results in Panel A suggest that EPL is positively related to COL and NOL, however, the base analysis is not appropriate for testing EPL's effect on DOL because DOL is estimated over a 5 year window. Therefore, Panel B shows EPL's effect on DOL when moving DOL i years into the future. When DOL is measured 3-5 years into the future, EPL is positively and significantly related to DOL, as hypothesized.

[Insert Table 9 here]

\section{Conclusion}

This paper tests the theories predicting an association of operating leverage with stock returns and the value premium. Consistent with the theories of Lev (1974) and Mandelker \& Rhee (1984) and the empirical findings of Garcia-Feijoo \& Jorgensen (2010), Novy-Marx (2011), and Gulen et al. (2011), COL, NOL, and DOL are positively related to monthly stock returns. Additionally, BFL is negatively related to stock returns and MFL is positively related to stock 
returns, and AMFL is mostly insignificantly related to stock returns. Additionally, results suggest that DOL, BFL, MFL, and AMFL are positively related to the value premium, while COL and NOL are negatively related to the value premium, consistent with the theory and evidence presented by Carlson et al. (2004), Garcia-Feijoo \& Jorgensen (2010), and Novy-Marx (2011). While prior studies have brought up the inherent trade-off of OL and FL, they have not taken steps to control for the potential endogeneity of this relationship. In order to control for the endogeneity of OL and FL, we jointly control for both OL and FL in regressions as well as orthogonalize each measure of OL from each measure of FL. While the orthogonalized results remain similar to the base results, it is important to see evidence of the effect, or lack thereof, of the trade-off of OL in FL in confounding the results without the endogeneity controls. Results additionally suggest that exogenous shocks to employment protection increase OL. 


\section{References}

Allard, Gayle. "Measuring job security over time: in search of a historical indicator for EPL (Employment Protection Legislation)." (2005). Working Paper.

Asness, Clifford S., Tobias J. Moskowitz, and Lasse Heje Pedersen. "Value and momentum everywhere." The Journal of Finance 68.3 (2013): 929-985.

Banz, Rolf W. "The relationship between return and market value of common stocks." Journal of Financial Economics 9.1 (1981): 3-18.

Basu, Sanjoy. "Investment performance of common stocks in relation to their priceearnings ratios: A test of the efficient market hypothesis." The Journal of Finance 32.3 (1977): 663-682.

Basu, Sanjoy. "The relationship between earnings' yield, market value and return for NYSE common stocks: Further evidence." Journal of Financial Economics 12.1 (1983): 129156.

Black, Fischer. "International capital market equilibrium with investment barriers." Journal of Financial Economics 1.4 (1974): 337-352.

Booth, Laurence. "The influence of production technology on risk and the cost of capital." Journal of Financial and Quantitative Analysis 26.01 (1991): 109-127.

Bremer, Marc, and Richard J. Sweeney. "The reversal of large stock-price decreases." The Journal of Finance 46.2 (1991): 747-754.

Campbell, John Y., Jens Hilscher, and Jan Szilagyi. "In search of distress risk." The Journal of Finance 63.6 (2008): 2899-2939.

Cao, Viet Nga. "What explains the value premium? The case of adjustment costs, operating leverage and financial leverage." Journal of Banking \& Finance 59 (2015): 350-366. 
Carlson, Murray, Adlai Fisher, and Ron Giammarino. "Corporate investment and asset price dynamics: implications for the cross-section of returns." The Journal of Finance 59.6 (2004): 2577-2603.

Chan, K. C., and Nai-Fu Chen. "Structural and return characteristics of small and large firms." The Journal of Finance 46.4 (1991): 1467-1484.

Chen, Zhiyao, Jarrad Harford, and Avraham Kamara. "Operating Leverage, Profitability and Capital Structure." (2016). Working Paper.

Chen, Huafeng Jason, Marcin Kacperczyk, and Hernan Ortiz-Molina. "Labor unions, operating flexibility, and the cost of equity." Journal of Financial and Quantitative Analysis 46.01 (2011): 25-58.

Chen, Nai-fu, and Feng Zhang. "Risk and return of value stocks." The Journal of Business 71.4 (1998): 501-535.

Choi, Jaewon. "What drives the value premium?: The role of asset risk and leverage." Review of Financial Studies 26.11 (2013): 2845-2875.

Danthine, Jean-Pierre, and John B. Donaldson. "Labour relations and asset returns." The Review of Economic Studies 69.1 (2002): 41-64.

DeBondt, Werner FM, and Richard Thaler. "Does the stock market overreact?" The Journal of Finance 40.3 (1985): 793-805.

Dessaint, Olivier, Andrey Golubov, and Paolo Volpin. "Employment protection and takeovers." Journal of Financial Economics 125.2 (2017): 369-388.

Djankov, Simeon, Caralee McLiesh, and Andrei Shleifer. "Private Credit in 129 Countries." Journal of Financial Economics 84.2 (2007): 299-329. 
Fama, Eugene F., and Kenneth R. French. "The cross-section of expected stock returns." The Journal of Finance 47.2 (1992): 427-465.

Fama, Eugene F., and Kenneth R. French. "Common risk factors in the returns on stocks and bonds." Journal of Financial Economics 33.1 (1993): 3-56.

Fama, Eugene F., and Kenneth R. French. "Multifactor explanations of asset pricing anomalies." The Journal of Finance 51.1 (1996): 55-84.

Fama, Eugene F., and Kenneth R. French. "Value versus growth: The international evidence." The Journal of Finance 53.6 (1998): 1975-1999.

Fama, Eugene F., and Kenneth R. French. "Profitability, investment and average returns." Journal of Financial Economics 82.3 (2006): 491-518.

Fama, Eugene F., and Kenneth R. French. "Dissecting anomalies." The Journal of Finance 63.4 (2008): 1653-1678.

Fama, Eugene F., and Kenneth R. French. "Size, value, and momentum in international stock returns." Journal of Financial Economics 105.3 (2012): 457-472.

Fama, Eugene F., and Kenneth R. French. "Dissecting anomalies with a five-factor model." The Review of Financial Studies 29.1 (2016): 69-103.

Frank, Murray Z., and Vidhan K. Goyal. "Capital structure decisions: which factors are reliably important?." Financial Management 38.1 (2009): 1-37.

García-Feijóo, Luis, and Randy D. Jorgensen. "Can operating leverage be the cause of the value premium?" Financial Management 39.3 (2010): 1127-1154.

Gulen, Huseyin, Yuhang Xing, and Lu Zhang. "Value versus Growth: Time-Varying Expected Stock Returns." Financial Management 40.2 (2011): 381-407. 
Guthrie, Graeme. "A note on operating leverage and expected rates of return." Finance Research Letters 8.2 (2011): 88-100.

Hackbarth, Dirk, and Timothy Johnson. "Real options and risk dynamics." The Review of Economic Studies 82.4 (2015): 1449-1482.

Hou, Kewei, G. Andrew Karolyi, and Bong-Chan Kho. "What factors drive global stock returns?." The Review of Financial Studies 24.8 (2011): 2527-2574.

Hou, Kewei, Chen Xue, and Lu Zhang. "Digesting anomalies: An investment approach." The Review of Financial Studies28.3 (2015): 650-705.

Huizinga, Harry, Luc Laeven, and Gaetan Nicodeme. "Capital structure and international debt shifting." Journal of Financial Economics 88.1 (2008): 80-118.

Huffman, Stephen P. "The impact of the degrees of operating and financial leverage on the systematic risk of common stocks: another look." Quarterly Journal of Business and Economics (1989): 83-100.

Ince, Ozgur S., and R. Burt Porter. "Individual equity return data from Thomson Datastream: Handle with care!." Journal of Financial Research 29.4 (2006): 463-479.

Jegadeesh, Narasimhan, and Sheridan Titman. "Returns to buying winners and selling losers: Implications for stock market efficiency." The Journal of Finance $48.1 \quad$ (1993): 65-91.

Jegadeesh, Narasimhan, and Sheridan Titman. "Profitability of momentum strategies: An evaluation of alternative explanations." The Journal of Finance 56.2 (2001): 699- 720.

Kahl, Matthias, Jason Lunn, and Mattias Nilsson. "Operating leverage and corporate financial policies." (2014). Working Paper. 
Lambrecht, Bart M., Grzegorz Pawlina, and Joao CA Teixeira. "Making, buying, and concurrent sourcing: implications for operating leverage and stock beta." Review of Finance 20.3 (2015): 1013-1043.

Lakonishok, Josef, Andrei Shleifer, and Robert W. Vishny. "Contrarian investment, extrapolation, and risk." The Journal of Finance 49.5 (1994): 1541-1578.

Lemmon, Michael L., Michael R. Roberts, and Jaime F. Zender. "Back to the beginning: persistence and the cross-section of corporate capital structure." The Journal of Finance 63.4 (2008): 1575-1608.

Lev, Baruch. "On the association between operating leverage and risk." Journal of Financial and Quantitative Analysis 9.04 (1974): 627-641.

Mandelker, Gershon N., and S. Ghon Rhee. "The impact of the degrees of operating and financial leverage on systematic risk of common stock." Journal of Financial and Quantitative Analysis 19.1 (1984): 45-57.

Marciukaityte, Dalia. "Right-to-Work Laws and Financial Leverage." Financial Management 44.1 (2015): 147-175.

Matsa, David A. "Capital structure as a strategic variable: Evidence from collective bargaining." The Journal of Finance 65.3 (2010): 1197-1232.

McDaniel, Wm R. "Operating leverage and operating risk." Journal of Business Finance \& Accounting 11.1 (1984): 113-125.

McLean, R. David, Jeffrey Pontiff, and Akiko Watanabe. "Share issuance and crosssectional returns: International evidence." Journal of Financial Economics 94.1 (2009): $1-17$. 
Merton, Robert C. "A simple model of capital market equilibrium with incomplete information." The Journal of Finance 42.3 (1987): 483-510.

Novy-Marx, Robert. "Operating leverage." Review of Finance 15.1 (2011): 103-134.

Novy-Marx, Robert. "The other side of value: The gross profitability premium." Journal of Financial Economics 108.1 (2013): 1-28.

O'Brien, Thomas J., and Paul A. Vanderheiden. "Empirical measurement of operating leverage for growing firms." Financial Management (1987): 45-53.

Ozdagli, Ali K. "Financial leverage, corporate investment, and stock returns." Review of Financial Studies 25.4 (2012): 1033-1069.

Penman, Stephen H., Scott A. Richardson, and Irem Tuna. "The Book-to-Price Effect in Stock Returns: Accounting for Leverage." Journal of Accounting Research 45.2 (2007): 427467.

Rajan, Raghuram G., and Luigi Zingales. "What do we know about capital structure? Some evidence from international data." The Journal of Finance 50.5 (1995): 1421-1460.

Rosenberg, Barr, Kenneth Reid, and Ronald Lanstein. "Persuasive evidence of market inefficiency." The Journal of Portfolio Management 11.3 (1985): 9-16.

Rosett, Joshua G. "Equity risk and the labor stock: the case of union contracts." Journal of Accounting Research 39.2 (2001): 337-364.

Ruback, Richard S., and Martin B. Zimmerman. "Unionization and profitability: Evidence from the capital market." Journal of Political Economy 92.6 (1984): 1134-1157.

Rubinstein, Mark E. "A mean-variance synthesis of corporate financial theory." The Journal of Finance 28.1 (1973): 167-181. 
Simintzi, Elena, Vikrant Vig, and Paolo Volpin. "Labor Protection and Leverage." Review of Financial Studies 28.2 (2015).

Stattman, Dennis. "Book values and stock returns." The Chicago MBA: A Journal of Selected Papers 4.1 (1980): 25-45.

Watanabe, Akiko, Yan Xu, Tong Yao, and Tong Yu. "The asset growth effect: Insights from international equity markets." Journal of Financial Economics108.2 (2013): 529-563.

Woods, Keegan, Kelvin Jui Keng Tan, and Robert Faff. "Labor unions and corporate financial leverage: The bargaining device versus crowding-out hypotheses." Journal of Financial Intermediation (2017).

Zhang, Lu. "The value premium." The Journal of Finance 60.1 (2005): 67-103. 


\section{Tables}

\section{Table 1}

\section{Summary Stats of Sampled Countries}

Table 1 presents summary statistics for each sampled country in Panel A, and in Panel B presents each country in the sample, the number of listed firms sampled from each country and the percentage of total firms each country has relative to the full sample. Column 2 presents the year data started for the sampled county. Column 3 presents the number of unique firms per country. Column 4 presents the percent of unique firms in each country. Column 5 presents the total average monthly market cap of sampled firms within each country, shown in millions. Column 6 presents the percent of the total sampled market cap of each country. Variables include: return (ret), the Chen et al. measure of operating leverage (COL), the Novy-Marx measure of operating leverage (NOL), the natural log of the degree of operating leverage (DOL), book financial leverage (BFL), the natural log of market financial leverage (MFL), the alternative market financial leverage (AMFL), book-to-market equity (BM), natural log of the market cap of the firm (SIZE)For each country, the average, standard deviation and number of observations are reported, in that order. Returns are taken monthly, and all other variables are gathered annuallyData are from 1980 through 2016.

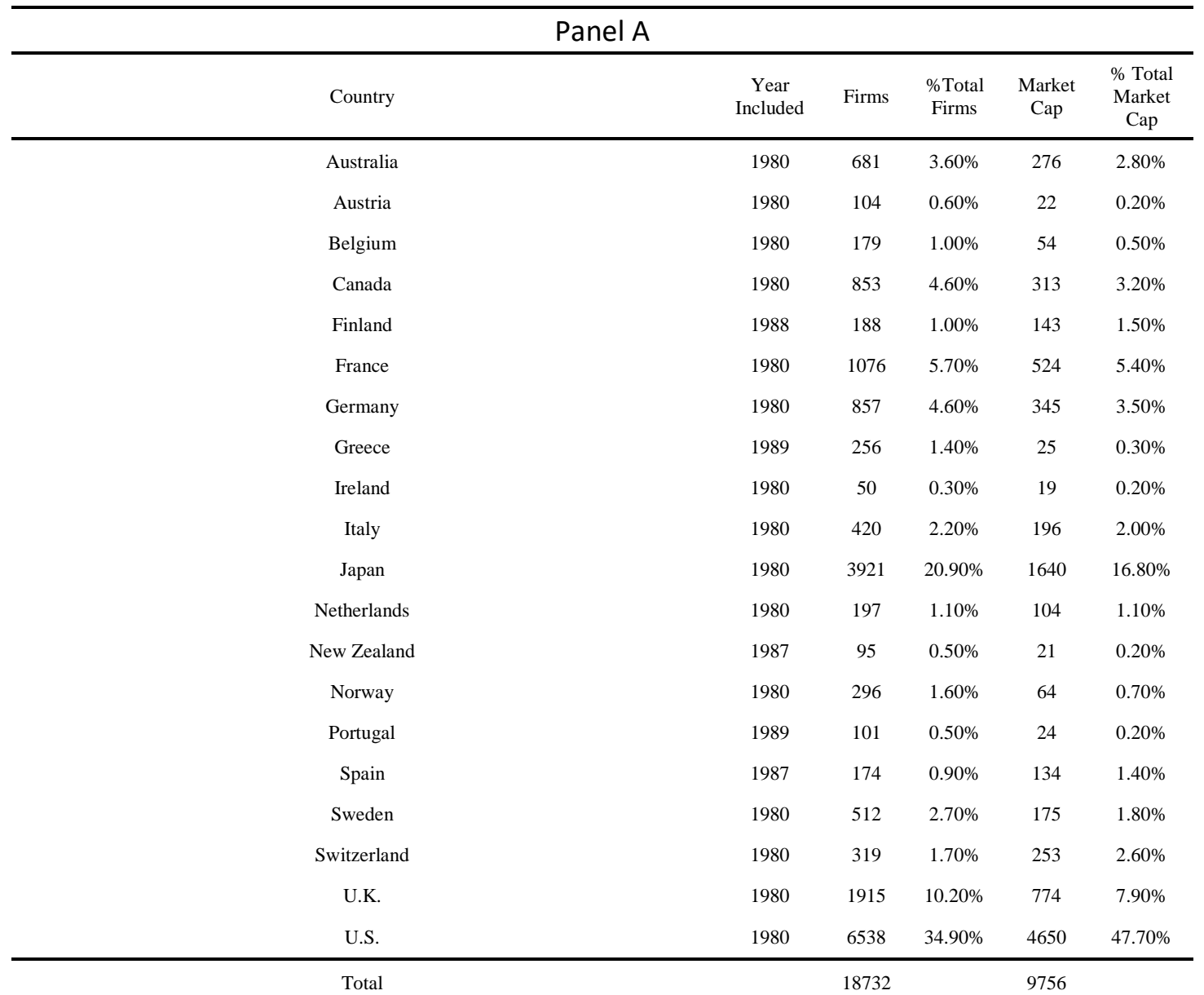


Panel B

\begin{tabular}{|c|c|c|c|c|c|c|c|c|c|c|c|c|c|c|c|c|c|c|c|}
\hline Country & RET & $\mathrm{col}$ & nol & dol & bfl & mlev & amlev & $\mathrm{bm}$ & size & Country & RET & $\mathrm{col}$ & nol & dol & bfl & mlev & amlev & $\mathrm{bm}$ & size \\
\hline \multirow[t]{3}{*}{ Australia } & 0.02 & 0.30 & 0.97 & 0.28 & 0.21 & -1.12 & 0.12 & -1.14 & 14.20 & Japan & 0.01 & 0.23 & 1.09 & 0.69 & 0.18 & -0.01 & 0.15 & -0.42 & 12.40 \\
\hline & 0.09 & 0.30 & 0.59 & 1.31 & 0.14 & 1.21 & 0.09 & 0.70 & 1.44 & & 0.10 & 0.18 & 0.55 & 1.66 & 0.16 & 1.57 & 0.14 & 0.72 & 1.87 \\
\hline & 9399 & 539 & 212 & 776 & 1041 & 1051 & 1041 & 1030 & 1031 & & 357875 & 33793 & 28004 & 23616 & 35682 & 35999 & 35682 & 35322 & 35322 \\
\hline \multirow[t]{3}{*}{ Austria } & 0.01 & 0.15 & 0.86 & 0.10 & 0.22 & 0.71 & 0.19 & -0.44 & 11.61 & Netherlands & 0.01 & 0.28 & 1.67 & -0.20 & 0.21 & 0.54 & 0.17 & -0.58 & 12.12 \\
\hline & 0.09 & 0.13 & 0.36 & 1.85 & 0.16 & 2.18 & 0.15 & 0.62 & 1.82 & & 0.09 & 0.20 & 1.10 & 1.89 & 0.15 & 1.70 & 0.13 & 0.76 & 2.22 \\
\hline & 11608 & 471 & 165 & 638 & 1036 & 1045 & 1035 & 1025 & 1025 & & 21794 & 1046 & 524 & 1358 & 1966 & 1981 & 1966 & 1947 & 1947 \\
\hline \multirow[t]{3}{*}{ Belgium } & 0.01 & 0.20 & 1.03 & 0.21 & 0.21 & 1.06 & 0.19 & -0.62 & 11.62 & New Zealand & 0.02 & 0.19 & 1.03 & 0.15 & 0.21 & -0.82 & 0.15 & -0.74 & 13.51 \\
\hline & 0.08 & 0.14 & 0.62 & 1.73 & 0.15 & 2.13 & 0.14 & 0.96 & 1.98 & & 0.07 & 0.10 & 0.60 & 1.09 & 0.11 & 0.85 & 0.10 & 0.61 & 1.30 \\
\hline & 21202 & 466 & 195 & 1216 & 1867 & 1884 & 1867 & 1849 & 1849 & & 579 & 26 & 4 & 57 & 78 & 78 & 78 & 78 & 78 \\
\hline \multirow[t]{3}{*}{ Canada } & 0.02 & 0.13 & 0.78 & 0.36 & 0.22 & -0.12 & 0.18 & -0.65 & 13.05 & Norway & 0.02 & 0.16 & 0.78 & 0.49 & 0.28 & 0.49 & 0.26 & -0.54 & 12.22 \\
\hline & 0.10 & 0.15 & 0.67 & 1.75 & 0.16 & 1.57 & 0.14 & 0.54 & 1.60 & & 0.10 & 0.15 & 0.58 & 1.75 & 0.18 & 1.52 & 0.19 & 0.75 & 1.67 \\
\hline & 35455 & 2423 & 857 & 2141 & 3308 & 3341 & 3308 & 3275 & 3275 & & 13738 & 785 & 426 & 748 & 1325 & 1337 & 1325 & 1310 & 1312 \\
\hline \multirow[t]{3}{*}{ Finland } & 0.01 & 0.22 & 1.16 & 0.23 & 0.24 & 0.64 & 0.21 & -0.72 & 12.36 & Portugal & 0.01 & 0.14 & 1.23 & 0.13 & 0.28 & 0.63 & 0.26 & -0.31 & 11.36 \\
\hline & 0.09 & 0.14 & 0.58 & 1.77 & 0.14 & 1.64 & 0.14 & 0.72 & 1.85 & & 0.08 & 0.12 & 0.95 & 1.77 & 0.18 & 1.41 & 0.17 & 0.74 & 1.98 \\
\hline & 17875 & 852 & 310 & 1181 & 1647 & 1662 & 1647 & 1631 & 1631 & & 5319 & 37 & 10 & 270 & 515 & 520 & 515 & 510 & 510 \\
\hline \multirow{3}{*}{$\begin{array}{l}\text { France } \\
\text { N }\end{array}$} & 0.01 & 0.21 & 0.89 & 0.30 & 0.20 & 0.66 & 0.18 & -0.49 & 11.63 & Spain & 0.01 & 0.13 & 0.66 & -0.21 & 0.23 & 0.47 & 0.20 & -0.55 & 13.03 \\
\hline & 0.10 & 0.15 & 0.41 & 1.81 & 0.14 & 1.71 & 0.13 & 0.70 & 2.04 & & 0.08 & 0.12 & 0.48 & 1.58 & 0.16 & 1.55 & 0.15 & 0.70 & 1.93 \\
\hline & 96024 & 1575 & 698 & 5051 & 8575 & 8660 & 8575 & 8489 & 8489 & & 14473 & 196 & 84 & 867 & 1348 & 1361 & 1348 & 1335 & 1335 \\
\hline \multirow[t]{3}{*}{ Germany } & 0.01 & 0.25 & 1.10 & 0.39 & 0.16 & 0.76 & 0.14 & -0.66 & 11.65 & Sweden & 0.01 & 0.24 & 1.10 & 0.19 & 0.21 & 0.84 & 0.18 & -0.81 & 12.22 \\
\hline & 0.09 & 0.18 & 0.65 & 1.85 & 0.15 & 1.91 & 0.13 & 0.63 & 2.03 & & 0.09 & 0.15 & 0.59 & 1.74 & 0.15 & 2.01 & 0.13 & 0.69 & 1.91 \\
\hline & 79596 & 3970 & 1825 & 4619 & 7203 & 7267 & 7203 & 7120 & 7125 & & 30128 & 1606 & 583 & 1833 & 2909 & 2937 & 2909 & 2880 & 2880 \\
\hline \multirow[t]{3}{*}{ Greece } & 0.02 & 0.14 & 0.72 & -0.25 & 0.22 & -0.23 & 0.16 & -1.00 & 11.75 & Switzerland & 0.01 & 0.20 & 0.96 & 0.25 & 0.23 & 1.81 & 0.22 & -0.61 & 11.18 \\
\hline & 0.15 & 0.13 & 0.52 & 1.54 & 0.17 & 1.37 & 0.15 & 0.84 & 1.54 & & 0.08 & 0.14 & 0.63 & 1.90 & 0.16 & 2.38 & 0.16 & 1.16 & 2.40 \\
\hline & 9383 & 880 & 515 & 531 & 1028 & 1036 & 1028 & 1018 & 1018 & & 49405 & 3105 & 1314 & 2868 & 4304 & 4347 & 4304 & 4261 & 4261 \\
\hline \multirow[t]{3}{*}{ Ireland } & 0.02 & 0.22 & 0.94 & 0.15 & 0.20 & -0.82 & 0.13 & -0.90 & 13.69 & U.K. & 0.02 & 0.26 & 1.13 & 0.13 & 0.18 & -0.70 & 0.12 & -1.06 & 13.45 \\
\hline & 0.09 & 0.18 & 1.33 & 1.54 & 0.17 & 0.95 & 0.11 & 0.69 & 1.56 & & 0.08 & 0.21 & 0.71 & 1.39 & 0.14 & 1.18 & 0.10 & 0.74 & 1.78 \\
\hline & 1974 & 133 & 54 & 160 & 193 & 194 & 193 & 192 & 192 & & 51529 & 4029 & 2694 & 3792 & 5514 & 5569 & 5514 & 5459 & 5459 \\
\hline \multirow[t]{3}{*}{ Italy } & 0.01 & 0.23 & 0.66 & 0.35 & 0.22 & 0.67 & 0.19 & -0.67 & 12.60 & U.S. & 0.02 & 0.27 & 1.09 & 0.44 & 0.21 & -0.21 & 0.16 & -0.75 & 12.92 \\
\hline & 0.09 & 0.16 & 0.42 & 1.56 & 0.14 & 2.03 & 0.13 & 0.78 & 1.86 & & 0.11 & 0.20 & 0.69 & 1.93 & 0.17 & 1.46 & 0.14 & 0.66 & 1.81 \\
\hline & 16639 & 1446 & 688 & 997 & 1693 & 1710 & 1693 & 1675 & 1676 & & 467889 & 39088 & 27127 & 26342 & 42151 & 42514 & 42151 & 41719 & 41726 \\
\hline
\end{tabular}




\section{Table 2}

Returns across Portfolio Sorts

Table 2 presents returns across independent variable quintile sorts. Variables include: monthly return (ret), the Chen et al. measure of operating leverage (COL), the Novy-Marx measure of operating leverage (NOL), the natural log of the degree of operating leverage (DOL), book financial leverage (BFL), the natural log of market financial leverage (MFL), the alternative market financial leverage (AMFL), book-to-market equity (BM), and natural log of the market cap of the firm (Size). Data are from 1980 through 2016.

\begin{tabular}{ccccccccc} 
Quintile & COL & NOL & DOL & BFL & MFL & AMFL & BM & SIZE \\
\hline 1 & 0.0070 & 0.0073 & 0.0068 & 0.0083 & 0.0045 & 0.0077 & 0.0081 & 0.0142 \\
2 & 0.0078 & 0.0067 & 0.0068 & 0.0087 & 0.0062 & 0.0078 & 0.0098 & 0.0119 \\
3 & 0.0075 & 0.0083 & 0.0079 & 0.0078 & 0.0072 & 0.0071 & 0.0114 & 0.0115 \\
4 & 0.0080 & 0.0076 & 0.0083 & 0.0068 & 0.0089 & 0.0069 & 0.0129 & 0.0113 \\
5 & 0.0085 & 0.0094 & 0.0090 & 0.0054 & 0.0103 & 0.0074 & 0.0141 & 0.0101 \\
\hline $5-1$ Difference & 0.0015 & 0.0022 & 0.0022 & -0.0028 & 0.0058 & -0.0003 & 0.0060 & -0.0040 \\
t-stat & $(1.39)$ & $(1.81)$ & $(2.10)$ & $(-2.88)$ & $(5.88)$ & $(-0.29)$ & $(3.94)$ & $(-2.75)$
\end{tabular}


Table 3

Fama-MacBeth Regressions Estimating Monthly Stock Return

Table 3 presents Fama-MacBeth Regressions estimating monthly stock return (RET). Column (1) presents regressions only controlling for country fixed effects. Panel A is the full sample, Panel B is the North American sample, Panel C is the European sample, and Panel D is the Asian Sample. The dependent variable is monthly stock return (RET). Independent variables include: the Chen et al. measure of operating leverage (COL), the Novy-Marx measure of operating leverage (NOL), the natural log of the degree of operating leverage (DOL), book financial leverage (BFL), the natural log of market financial leverage (MFL), the alternative market financial leverage (AMFL). Controls include the natural log of book-to-market equity (BM), the natural log of the market cap of the firm (SIZE), the prior month's return (lret), the return over the prior 11 months from t-2 through t-12 (MOM), and country fixed effects. Data are from 1980 through 2016.*, **, and *** represent statistical significance at the $10 \%, 5 \%$, and $1 \%$ respectively.

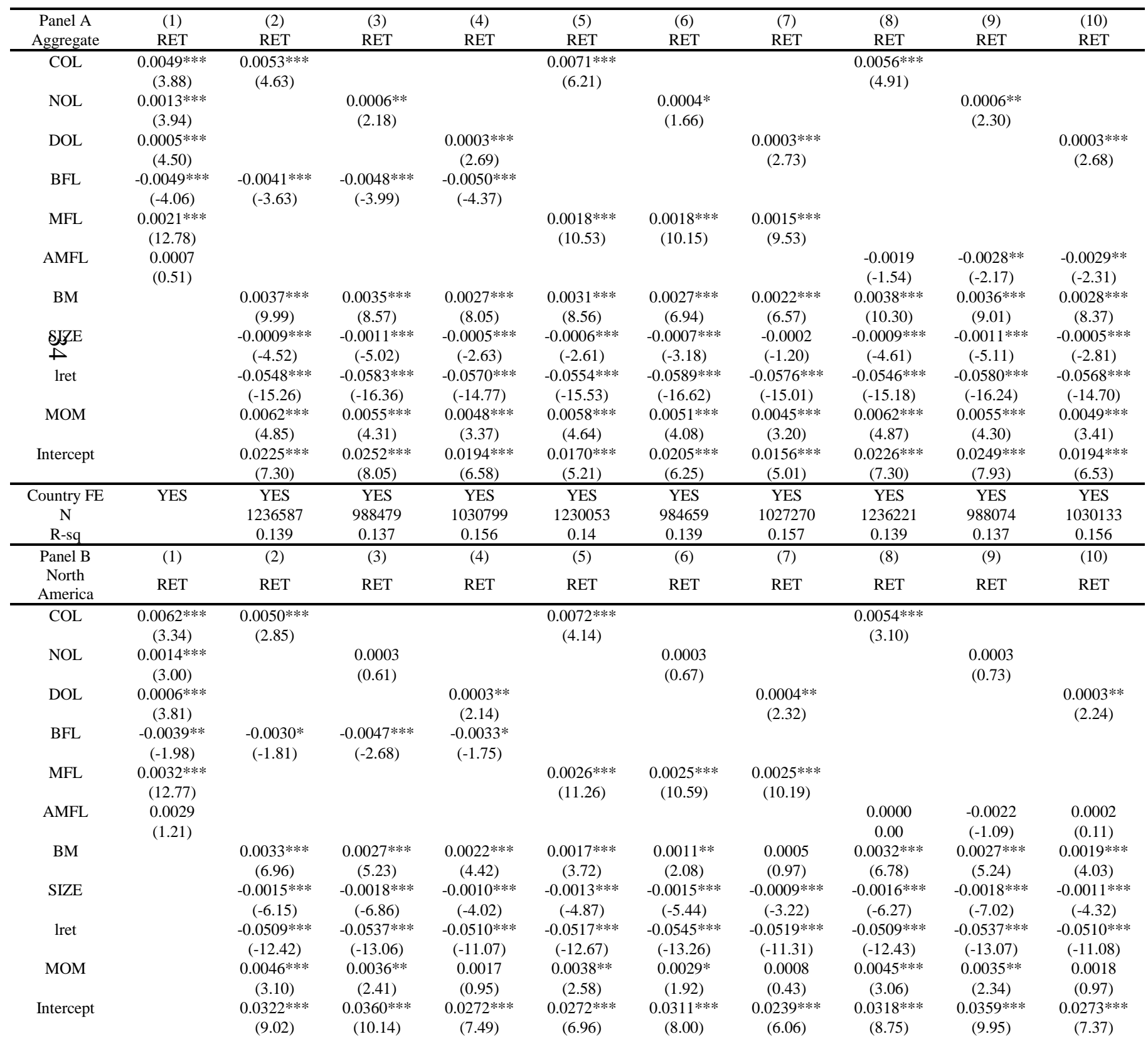




\begin{tabular}{|c|c|c|c|c|c|c|c|c|c|c|}
\hline Country FE & YES & YES & YES & YES & YES & YES & YES & YES & YES & YES \\
\hline $\mathrm{N}$ & & 464255 & 367169 & 332825 & 461727 & 365399 & 331403 & 464287 & 367148 & 332673 \\
\hline R-sq & & 0.049 & 0.046 & 0.05 & 0.05 & 0.048 & 0.051 & 0.049 & 0.046 & 0.05 \\
\hline Panel C & $(1)$ & $(2)$ & $(3)$ & (4) & $(5)$ & $(6)$ & $(7)$ & $(8)$ & $(9)$ & (10) \\
\hline Europe & RET & RET & RET & RET & RET & RET & RET & RET & RET & RET \\
\hline $\mathrm{COL}$ & $\begin{array}{c}0.0016 \\
-0.80\end{array}$ & $\begin{array}{c}0.0066^{*} \\
-1.76\end{array}$ & & & $\begin{array}{c}0.0042^{* *} \\
-2.07\end{array}$ & & & $\begin{array}{c}0.0066^{*} \\
-1.78\end{array}$ & & \\
\hline NOL & $\begin{array}{c}0.0006 \\
-1.08\end{array}$ & & $\begin{array}{c}0.0001 \\
-0.14\end{array}$ & & & $\begin{array}{c}0.0005 \\
-1.11\end{array}$ & & & $\begin{array}{c}0.0001 \\
-0.21\end{array}$ & \\
\hline DOL & $\begin{array}{c}0.0007 * * * \\
-3.84\end{array}$ & & & $\begin{array}{c}0.0004 * * \\
-2.37\end{array}$ & & & $\begin{array}{c}0.0004 * * \\
-2.20\end{array}$ & & & $\begin{array}{c}0.0004^{* *} \\
-2.38\end{array}$ \\
\hline BFL & $\begin{array}{c}-0.0061 * * * \\
(-4.28)\end{array}$ & $\begin{array}{c}-0.0039 \\
(-1.57)\end{array}$ & $\begin{array}{c}-0.0042^{*} \\
(-1.71)\end{array}$ & $\begin{array}{c}-0.0087 * * * \\
(-4.63)\end{array}$ & & & & & & \\
\hline MFL & $\begin{array}{c}0.0017 * * * \\
-12.07\end{array}$ & & & & $\begin{array}{c}0.0016^{* * * *} \\
-4.04\end{array}$ & $\begin{array}{c}0.0016^{* * * *} \\
-3.49\end{array}$ & $\begin{array}{c}0.0008 * * * \\
-4.28\end{array}$ & & & \\
\hline AMFL & $\begin{array}{c}-0.0002 \\
(-0.11)\end{array}$ & & & & & & & $\begin{array}{c}-0.0018 \\
(-0.64)\end{array}$ & $\begin{array}{r}-0.0024 \\
(-0.90)\end{array}$ & $\begin{array}{c}-0.0073 * * * \\
(-3.56)\end{array}$ \\
\hline $\mathrm{BM}$ & & $\begin{array}{c}0.0028 * * * \\
-3.75\end{array}$ & $\begin{array}{c}0.0028 * * * \\
-4.13\end{array}$ & $\begin{array}{c}0.0028 * * * \\
-8.19\end{array}$ & $\begin{array}{c}0.0028 \text { *** } \\
-3.55\end{array}$ & $\begin{array}{c}0.0026 * * * \\
-3.62\end{array}$ & $\begin{array}{c}0.0026 * * * \\
-7.52\end{array}$ & $\begin{array}{c}0.0028 * * * \\
-3.70\end{array}$ & $\begin{array}{c}0.0030 * * * \\
-4.25\end{array}$ & $\begin{array}{c}0.0030 * * * \\
-8.59\end{array}$ \\
\hline SIZE & & $\begin{array}{c}0.0001 \\
-0.16\end{array}$ & $\begin{array}{c}-0.0003 \\
(-0.84)\end{array}$ & $\begin{array}{c}-0.0004^{*} \\
(-1.87)\end{array}$ & $\begin{array}{c}-0.0001 \\
(-0.25)\end{array}$ & $\begin{array}{c}0.0001 \\
-0.15\end{array}$ & $\begin{array}{c}-0.0002 \\
(-0.93)\end{array}$ & $\begin{array}{c}0 \\
(-0.02)\end{array}$ & $\begin{array}{c}-0.0004 \\
(-0.98)\end{array}$ & $\begin{array}{c}-0.0005 * * \\
(-2.12)\end{array}$ \\
\hline lret & & $\begin{array}{c}-0.0360 * * * \\
(-7.39)\end{array}$ & $\begin{array}{c}-0.0389 * * * \\
(-8.01)\end{array}$ & $\begin{array}{c}-0.0549 * * * \\
(-12.65)\end{array}$ & $\begin{array}{c}-0.0339 * * * \\
(-5.96)\end{array}$ & $\begin{array}{c}-0.0376 * * * \\
(-7.72)\end{array}$ & $\begin{array}{c}-0.0538 * * * \\
(-12.44)\end{array}$ & $\begin{array}{c}-0.0369 * * * \\
(-7.90)\end{array}$ & $\begin{array}{c}-0.0386 * * * \\
(-7.94)\end{array}$ & $\begin{array}{c}-0.0544 * * * \\
(-12.55)\end{array}$ \\
\hline MOM & & $\begin{array}{c}0.0086 * * * \\
-3.34\end{array}$ & $\begin{array}{c}0.0113 \text { *** } \\
-7.42\end{array}$ & $\begin{array}{c}0.0107 * * * \\
-6.36\end{array}$ & $\begin{array}{c}0.0122 * * * \\
-5.02\end{array}$ & $\begin{array}{c}0.0112 * * * \\
-7.30\end{array}$ & $\begin{array}{c}0.0107 * * * \\
-6.43\end{array}$ & $\begin{array}{c}0.0080 * * * \\
-2.85\end{array}$ & $\begin{array}{c}0.0114 * * * \\
-7.54\end{array}$ & $\begin{array}{c}0.0108 * * * \\
-6.46\end{array}$ \\
\hline Intercept & & $\begin{array}{c}0.0108 \\
-1.59 \\
\end{array}$ & $\begin{array}{c}0.0174 * * * \\
-3.34 \\
\end{array}$ & $\begin{array}{c}0.0179 * * * \\
-5.94\end{array}$ & $\begin{array}{c}0.0107 \text { *** } \\
-2.60 \\
\end{array}$ & $\begin{array}{c}0.0102 * * \\
-1.97\end{array}$ & $\begin{array}{c}0.0143 * * * \\
-4.27 \\
\end{array}$ & $\begin{array}{c}0.0112^{*} \\
-1.65\end{array}$ & $\begin{array}{c}0.0177 * * * \\
-3.40\end{array}$ & $\begin{array}{c}0.0181 \text { *** } \\
-6.01\end{array}$ \\
\hline $\begin{array}{c}\text { Country FE } \\
\mathrm{N} \\
\text { R-sq }\end{array}$ & YES & $\begin{array}{c}\text { YES } \\
308194 \\
0.187 \\
\end{array}$ & $\begin{array}{c}\text { YES } \\
208382 \\
0.191 \\
\end{array}$ & $\begin{array}{c}\text { YES } \\
333153 \\
0.151 \\
\end{array}$ & $\begin{array}{c}\text { YES } \\
306500 \\
0.189 \\
\end{array}$ & $\begin{array}{c}\text { YES } \\
207689 \\
0.193 \\
\end{array}$ & $\begin{array}{c}\text { YES } \\
331561 \\
0.152 \\
\end{array}$ & $\begin{array}{c}\text { YES } \\
308274 \\
0.187\end{array}$ & $\begin{array}{c}\text { YES } \\
208431 \\
0.191 \\
\end{array}$ & $\begin{array}{c}\text { YES } \\
333023 \\
0.151 \\
\end{array}$ \\
\hline $\begin{array}{c}\text { Panel D } \\
\text { Asia }\end{array}$ & $\begin{array}{c}(1) \\
\text { RET }\end{array}$ & $\begin{array}{c}(2) \\
\text { RET }\end{array}$ & $\begin{array}{c}(3) \\
\text { RET }\end{array}$ & $\begin{array}{c}(4) \\
\text { RET }\end{array}$ & $\begin{array}{c}(5) \\
\text { RET }\end{array}$ & $\begin{array}{c}(6) \\
\text { RET }\end{array}$ & $\begin{array}{c}(7) \\
\text { RET }\end{array}$ & $\begin{array}{c}(8) \\
\text { RET }\end{array}$ & $\begin{array}{c}(9) \\
\text { RET }\end{array}$ & $\begin{array}{l}(10) \\
\text { RET }\end{array}$ \\
\hline $\mathrm{COL}$ & $\begin{array}{c}0.0028 \\
(1.14)\end{array}$ & $\begin{array}{c}0.0041 * \\
(1.84)\end{array}$ & & & $\begin{array}{c}0.0054 * * \\
(2.47)\end{array}$ & & & $\begin{array}{c}0.0043^{*} \\
(1.94)\end{array}$ & & \\
\hline NOL & $\begin{array}{c}0.0006 \\
(1.18)\end{array}$ & & $\begin{array}{c}0.0008 \\
(1.57)\end{array}$ & & & $\begin{array}{c}0.0003 \\
(0.73)\end{array}$ & & & $\begin{array}{c}0.0008^{*} \\
(1.65)\end{array}$ & \\
\hline DOL & $\begin{array}{c}-0.0002 \\
(-0.81)\end{array}$ & & & $\begin{array}{c}-0.0002 \\
(-1.10)\end{array}$ & & & $\begin{array}{c}-0.0002 \\
(-0.84)\end{array}$ & & & $\begin{array}{c}-0.0002 \\
(-1.08)\end{array}$ \\
\hline BFL & $\begin{array}{c}-0.0047 * * \\
(-2.07)\end{array}$ & $\begin{array}{c}-0.0005 \\
(-0.20)\end{array}$ & $\begin{array}{c}0.0005 \\
-0.21\end{array}$ & $\begin{array}{c}-0.0014 \\
(-0.58)\end{array}$ & & & & & & \\
\hline MFL & $\begin{array}{c}0.0013 * * * \\
\quad(3.94)\end{array}$ & & & & $\begin{array}{c}0.0014 * * * \\
\quad(4.65)\end{array}$ & $\begin{array}{c}0.0013 * * * \\
\quad(4.13)\end{array}$ & $\begin{array}{c}0.0009^{* *} \\
(2.56)\end{array}$ & & & \\
\hline AMFL & $\begin{array}{c}0.0001 \\
(0.04)\end{array}$ & & & & & & & $\begin{array}{c}0.0016 \\
(0.55)\end{array}$ & $\begin{array}{l}0.003 \\
(0.95)\end{array}$ & $\begin{array}{c}-0.0005 \\
(-0.19)\end{array}$ \\
\hline $\mathrm{BM}$ & & $\begin{array}{c}0.0044 * * * \\
\quad(5.93)\end{array}$ & $\begin{array}{c}0.0045 * * * \\
(5.83)\end{array}$ & $\begin{array}{c}0.0052 * * * \\
\quad(6.01)\end{array}$ & $\begin{array}{c}0.0042 \text { *** } \\
\quad(6.05)\end{array}$ & $\begin{array}{c}0.0043 * * * \\
(5.89)\end{array}$ & $\begin{array}{c}0.0050 * * * \\
\quad(5.98)\end{array}$ & $\begin{array}{c}0.0045^{* * *} * \\
\quad(6.24)\end{array}$ & $\begin{array}{c}0.0045^{* * *} * \\
\quad(6.11)\end{array}$ & $\begin{array}{c}0.0053 \text { *** } \\
(6.14)\end{array}$ \\
\hline SIZE & & $\begin{array}{c}-0.0001 \\
(-0.12)\end{array}$ & $\begin{array}{c}-0.0002 \\
(-0.41)\end{array}$ & $\begin{array}{c}0.0004 \\
(0.71)\end{array}$ & $\begin{array}{c}0.0002 \\
(0.50)\end{array}$ & $\begin{array}{c}0.0001 \\
(0.15)\end{array}$ & $\begin{array}{c}0.0005 \\
(1.00)\end{array}$ & $\begin{array}{c}-0.0001 \\
(-0.15)\end{array}$ & $\begin{array}{c}-0.0002 \\
(-0.42)\end{array}$ & $\begin{array}{c}0.0003 \\
(0.70)\end{array}$ \\
\hline lret & & $\begin{array}{c}-0.0749 * * * \\
(-11.84)\end{array}$ & $\begin{array}{c}-0.0763 * * * \\
(-11.89)\end{array}$ & $\begin{array}{c}-0.0813^{* * *} \\
(-11.36)\end{array}$ & $\begin{array}{c}-0.0751 * * * \\
(-11.92)\end{array}$ & $\begin{array}{c}-0.0763^{* * *} * \\
(-11.95)\end{array}$ & $\begin{array}{c}-0.0816^{* * *} \\
(-11.49)\end{array}$ & $\begin{array}{c}-0.0745 * * * \\
(-11.76)\end{array}$ & $\begin{array}{c}-0.0758 * * * \\
(-11.78)\end{array}$ & $\begin{array}{c}-0.0810^{* * * *} \\
(-11.28)\end{array}$ \\
\hline MOM & & $\begin{array}{c}0.0019 \\
(0.81)\end{array}$ & $\begin{array}{c}0.0012 \\
(0.47)\end{array}$ & $\begin{array}{c}0.0009 \\
(0.34)\end{array}$ & $\begin{array}{c}0.0019 \\
(0.80)\end{array}$ & $\begin{array}{l}0.001 \\
(0.40)\end{array}$ & $\begin{array}{l}0.001 \\
(0.39)\end{array}$ & $\begin{array}{l}0.002 \\
(0.82)\end{array}$ & $\begin{array}{c}0.0011 \\
(0.45)\end{array}$ & $\begin{array}{c}0.0008 \\
(0.31)\end{array}$ \\
\hline Intercept & & $\begin{array}{c}0.0094 \\
(1.44) \\
\end{array}$ & $\begin{array}{c}0.0109 * \\
(1.73) \\
\end{array}$ & $\begin{array}{l}0.006 \\
(0.78) \\
\end{array}$ & $\begin{array}{c}0.0054 \\
(0.81) \\
\end{array}$ & $\begin{array}{c}0.0083 \\
(1.28) \\
\end{array}$ & $\begin{array}{c}0.0038 \\
(0.50) \\
\end{array}$ & $\begin{array}{c}0.0093 \\
(1.43) \\
\end{array}$ & $\begin{array}{c}0.0107^{*} \\
(1.70) \\
\end{array}$ & $\begin{array}{r}0.0059 \\
(0.78) \\
\end{array}$ \\
\hline Country FE & YES & YES & YES & YES & YES & YES & YES & YES & YES & YES \\
\hline $\mathrm{N}$ & & 464138 & 412928 & 364821 & 461826 & 411571 & 364306 & 463660 & 412495 & 364437 \\
\hline $\mathrm{R}$-sq & & 0.093 & 0.088 & 0.118 & 0.093 & 0.088 & 0.118 & 0.093 & 0.088 & 0.118 \\
\hline
\end{tabular}




\section{Table 4}

Orthogonal Fama-MacBeth Regressions Estimating Monthly Stock Return

Table 4 presents Fama-MacBeth Regressions estimating monthly stock return (RET) using orthogonalized leverage. The dependent variable is monthly stock return (RET). Independent variables include: the Chen et al. measure of operating leverage (COL), the Novy-Marx measure of operating leverage (NOL), the natural log of the degree of operating leverage (DOL), book financial leverage (BFL), the natural log of market financial leverage (MFL), the alternative market financial leverage (AMFL). Each measure of operating leverage is orthogonalized to financial leverage within each specificationControls include the natural $\log$ of book-to-market equity (BM), the natural log of the market cap of the firm (SIZE), the prior month's return (lret), the return over the prior 11 months from t-2 through t-12 (MOM), and country fixed effects. Data are from 1980 through $2016 . *, * *$, and *** represent statistical significance at the $10 \%$, $5 \%$, and $1 \%$ respectively.

\begin{tabular}{|c|c|c|c|c|c|c|c|c|c|}
\hline & (1) & (2) & (3) & (4) & (5) & (6) & (7) & (8) & (9) \\
\hline & RET & RET & RET & RET & RET & RET & RET & RET & RET \\
\hline \multirow[t]{2}{*}{$\mathrm{COL}$} & $0.0011^{* * *}$ & & & $0.0011 * * *$ & & & $0.0011 * * *$ & & \\
\hline & (5.09) & & & $(5.25)$ & & & $(5.05)$ & & \\
\hline \multirow[t]{2}{*}{ NOL } & & $0.0005^{* * *}$ & & & $0.0006 * * *$ & & & $0.0004 * *$ & \\
\hline & & $(2.65)$ & & & (3.44) & & & (2.51) & \\
\hline \multirow[t]{2}{*}{ DOL } & & & $0.0003 * * *$ & & & $0.0003 * *$ & & & $0.0003 * * *$ \\
\hline & & & (2.99) & & & (2.32) & & & (2.73) \\
\hline \multirow[t]{2}{*}{ BFL } & $-0.0006^{* * * *}$ & $-0.0008^{* * * *}$ & $-0.0008 * * *$ & & & & & & \\
\hline & $(-3.63)$ & $(-3.99)$ & $(-4.37)$ & & & & & & \\
\hline \multirow[t]{2}{*}{ MFL } & & & & $0.0027 * * *$ & $0.0025 * * *$ & $0.0022 * * *$ & & & \\
\hline & & & & (10.53) & (10.15) & $(9.53)$ & & & \\
\hline \multirow[t]{2}{*}{ AMFL } & & & & & & & -0.0003 & $-0.0004 * *$ & $-0.0004 * *$ \\
\hline & & & & & & & $(-1.54)$ & $(-2.17)$ & $(-2.31)$ \\
\hline BM & $0.0037 * * *$ & $0.0035^{* * * *}$ & $0.0027 * * *$ & $0.0031^{* * *}$ & $0.0027 * * *$ & $0.0022^{* * * *}$ & $0.0038^{* * *}$ & $0.0036 * * *$ & $0.0028 * * *$ \\
\hline
\end{tabular}




\begin{tabular}{|c|c|c|c|c|c|c|c|c|c|}
\hline & (9.99) & (8.57) & $(8.05)$ & (8.56) & $(6.94)$ & $(6.57)$ & $(10.30)$ & (9.01) & (8.37) \\
\hline \multirow[t]{2}{*}{ SIZE } & $-0.0009^{* * *}$ & $-0.0011 * * *$ & $-0.0005^{* * *}$ & $-0.0006^{* * *}$ & $-0.0007 * * *$ & -0.0002 & $-0.0009^{* * *}$ & $-0.0011 * * *$ & $-0.0005 * * *$ \\
\hline & $(-4.52)$ & $(-5.02)$ & $(-2.63)$ & $(-2.61)$ & $(-3.18)$ & $(-1.20)$ & $(-4.61)$ & $(-5.11)$ & $(-2.81)$ \\
\hline \multirow[t]{2}{*}{ lret } & $-0.0548 * * *$ & $-0.0583 * * *$ & $-0.0570 * * *$ & $-0.0554 * * *$ & $-0.0589 * * *$ & $-0.0576 * * *$ & $-0.0546 * * *$ & $-0.0580 * * *$ & $-0.0568 * * *$ \\
\hline & $(-15.26)$ & $(-16.36)$ & $(-14.77)$ & $(-15.53)$ & $(-16.62)$ & $(-15.01)$ & $(-15.18)$ & $(-16.24)$ & $(-14.70)$ \\
\hline \multirow[t]{2}{*}{ MOM } & $0.0062 * * *$ & $0.0055 * * *$ & $0.0048 * * *$ & $0.0058^{* * *}$ & $0.0051 * * *$ & $0.0045 * * *$ & $0.0062 * * *$ & $0.0055^{* * *}$ & $0.0049 * * *$ \\
\hline & $(4.85)$ & $(4.31)$ & $(3.37)$ & $(4.64)$ & $(4.08)$ & $(3.20)$ & (4.87) & $(4.30)$ & $(3.41)$ \\
\hline \multirow[t]{2}{*}{ Intercept } & $0.0230 * * *$ & $0.0249 * * *$ & $0.0183^{* * * *}$ & $0.0189^{* * * *}$ & $0.0211^{* * * *}$ & $0.0158 * * *$ & $0.0237 * * *$ & $0.0251 * * *$ & $0.0188 * * *$ \\
\hline & (7.56) & (7.99) & $(6.25)$ & (5.94) & $(6.52)$ & $(5.12)$ & (7.80) & (8.08) & $(6.41)$ \\
\hline Country FE & YES & YES & YES & YES & YES & YES & YES & YES & YES \\
\hline $\mathrm{N}$ & 1236587 & 988479 & 1030799 & 1230053 & 984659 & 1027270 & 1236221 & 988074 & 1030133 \\
\hline R-sq & 0.139 & 0.137 & 0.156 & 0.14 & 0.139 & 0.157 & 0.139 & 0.137 & 0.156 \\
\hline
\end{tabular}




\section{Table 5}

Univariate Sorts of Book-to-Market across Independent Variables

Table 5 presents univariate sorts of book-to-market (BM) across independent variables. Variables include: the Chen et al. measure of operating leverage (COL), the Novy-Marx measure of operating leverage (NOL), the natural log of the degree of operating leverage (DOL), book financial leverage (BFL), the natural log of market financial leverage (MFL), the alternative market financial leverage (AMFL). Data are from 1980 through 2016.

\begin{tabular}{ccccccc} 
Quintile & col & nol & dol & bfl & mfl & amfl \\
\hline 1 & 0.817 & 0.815 & 0.732 & 0.724 & 0.598 & 0.664 \\
2 & 0.784 & 0.755 & 0.723 & 0.770 & 0.703 & 0.688 \\
3 & 0.732 & 0.752 & 0.719 & 0.806 & 0.787 & 0.729 \\
4 & 0.656 & 0.746 & 0.807 & 0.825 & 0.884 & 0.848 \\
5 & 0.577 & 0.676 & 0.845 & 0.784 & 0.957 & 0.977 \\
\hline $5-1$ & & & & & & \\
\hline Difference & -0.241 & -0.139 & 0.113 & 0.061 & 0.359 & 0.313 \\
t-stat & $(-12.27)$ & $(-5.91)$ & $(2.91)$ & $(3.00)$ & $(17.49)$ & $(14.06)$
\end{tabular}




\section{Table 6}

OLS Book-to-Market Equity Regressions

Table 6 presents OLS regressions estimating book-to-market equity (bm). Panel A is the full sample, Panel B is the North American sample, Panel C is the European sample, and Panel D is the Asian Sample. Independent variables include: the Chen et al. measure of operating leverage (COL), the Novy-Marx measure of operating leverage (NOL), the natural log of the degree of operating leverage (DOL), book financial leverage (BFL), the natural log of market financial leverage (MFL), the alternative market financial leverage (AMFL), the natural log of sales (SALES), the rolling 5-year standard deviation of sales (SALES_SD), net income scaled by assets (NIA), tangibility measured as property, plant, and equipment scaled by assets (TANG). Additionally controlled for are industry, year, and country fixed effects. Data are from 1980 through 2016. *,**, and *** represent statistical significance at the $10 \%, 5 \%$, and $1 \%$ respectively. Standard errors are clustered at the firm level.

\begin{tabular}{|c|c|c|c|c|c|c|c|c|c|c|}
\hline $\begin{array}{c}\text { Panel A } \\
\text { Aggregate }\end{array}$ & $\begin{array}{l}(1) \\
\text { bm }\end{array}$ & $\begin{array}{l}(2) \\
\text { bm }\end{array}$ & $\begin{array}{l}(3) \\
\mathrm{bm}\end{array}$ & $\begin{array}{l}(4) \\
\mathrm{bm}\end{array}$ & $\begin{array}{l}(5) \\
\mathrm{bm}\end{array}$ & $\begin{array}{l}(6) \\
\mathrm{bm}\end{array}$ & $\begin{array}{l}(7) \\
\mathrm{bm}\end{array}$ & $\begin{array}{l}(8) \\
\mathrm{bm}\end{array}$ & $\begin{array}{l}\text { (9) } \\
\text { bm }\end{array}$ & $\begin{array}{l}(10) \\
\mathrm{bm}\end{array}$ \\
\hline col & $\begin{array}{c}-0.4893 * * * \\
(-15.36)\end{array}$ & $\begin{array}{c}-0.4789 * * * \\
(-14.72)\end{array}$ & & & $\begin{array}{c}-0.4330 * * * \\
(-13.57)\end{array}$ & & & $\begin{array}{c}-0.3810 * * * \\
(-12.00)\end{array}$ & & \\
\hline nol & $\begin{array}{c}-0.0145 \\
(-1.34)\end{array}$ & & $\begin{array}{c}0.0247 * * \\
(2.26)\end{array}$ & & & $\begin{array}{c}-0.0118 \\
(-1.08)\end{array}$ & & & $\begin{array}{c}0.0375 * * * \\
(3.55)\end{array}$ & \\
\hline dol & $\begin{array}{c}0.0284 * * * \\
(9.80)\end{array}$ & & & $\begin{array}{c}0.0242 * * * \\
(8.47)\end{array}$ & & & $\begin{array}{c}0.0222 * * * \\
\quad(7.84)\end{array}$ & & & $\begin{array}{c}0.0249 * * * \\
(8.83)\end{array}$ \\
\hline bfl & $\begin{array}{c}-0.0048 \\
(-0.16)\end{array}$ & $\begin{array}{c}-0.1766 * * * \\
(-5.37)\end{array}$ & $\begin{array}{c}-0.1804 * * * \\
(-4.88)\end{array}$ & $\begin{array}{c}-0.1036^{* *} \\
(-2.56)\end{array}$ & & & & & & \\
\hline $\mathrm{mfl}$ & $\begin{array}{c}0.0882 * * * \\
(26.56)\end{array}$ & & & & $\begin{array}{c}0.0769 * * * \\
(20.57)\end{array}$ & $\begin{array}{c}0.0827 * * * * \\
(19.09)\end{array}$ & $\begin{array}{c}0.0889 * * * \\
(18.49)\end{array}$ & & & \\
\hline amfl & $\begin{array}{c}0.9332 * * * \\
(29.15)\end{array}$ & & & & & & & $\begin{array}{c}0.7986^{* * * *} \\
(22.45)\end{array}$ & $\begin{array}{c}0.7764 * * * \\
(19.94)\end{array}$ & $\begin{array}{c}0.8721 * * * \\
(20.85)\end{array}$ \\
\hline Insales & & $\begin{array}{c}-0.0252 * * * \\
(-7.40)\end{array}$ & $\begin{array}{c}-0.0237 * * * \\
(-6.33)\end{array}$ & $\begin{array}{c}-0.0384 * * * \\
(-8.48)\end{array}$ & $\begin{array}{c}-0.0069 * \\
(-1.89)\end{array}$ & $\begin{array}{c}-0.0019 \\
(-0.43)\end{array}$ & $\begin{array}{c}-0.0220 * * * \\
(-4.79)\end{array}$ & $\begin{array}{c}-0.0298 * * * \\
(-8.71)\end{array}$ & $\begin{array}{c}-0.0291 * * * \\
(-7.56)\end{array}$ & $\begin{array}{c}-0.0465 * * * \\
(-10.45)\end{array}$ \\
\hline $\begin{array}{c}\text { sales_sd } \\
\omega\end{array}$ & & $\begin{array}{c}-0.0000 * * * \\
(-3.15)\end{array}$ & $\begin{array}{c}-0.0000 \\
(-1.38)\end{array}$ & $\begin{array}{c}-0.0000^{* *} \\
(-2.53)\end{array}$ & $\begin{array}{c}-0.0000 * * * \\
(-3.71)\end{array}$ & $\begin{array}{c}-0.0000 \\
(-1.57)\end{array}$ & $\begin{array}{c}-0.0000 * * * \\
(-3.60)\end{array}$ & $\begin{array}{c}-0.0000 * * * \\
(-3.28)\end{array}$ & $\begin{array}{c}-0.0000 \\
(-1.39)\end{array}$ & $\begin{array}{c}-0.0000 * * * \\
(-3.08)\end{array}$ \\
\hline nio & & $\begin{array}{c}-0.0660 * * * * \\
(-18.39)\end{array}$ & $\begin{array}{c}-0.0795 * * * \\
(-17.85)\end{array}$ & $\begin{array}{c}-0.0798 * * * \\
(-9.94)\end{array}$ & $\begin{array}{c}-0.0476 \text { *** } \\
(-14.22)\end{array}$ & $\begin{array}{c}-0.0602 * * * * \\
(-14.09)\end{array}$ & $\begin{array}{c}-0.0455^{* * * *} \\
(-6.00)\end{array}$ & $\begin{array}{c}-0.0609 * * * \\
(-17.43)\end{array}$ & $\begin{array}{c}-0.0740 * * * \\
(-16.79)\end{array}$ & $\begin{array}{c}-0.0734 * * * \\
(-9.06)\end{array}$ \\
\hline tangibility & & $\begin{array}{c}0.5242 * * * \\
(15.86)\end{array}$ & $\begin{array}{c}0.6203^{* * * *} \\
(16.48)\end{array}$ & $\begin{array}{c}0.4619 * * * \\
(11.79)\end{array}$ & $\begin{array}{c}0.4380 * * * \\
(13.88)\end{array}$ & $\begin{array}{c}0.5120 * * * \\
(13.81)\end{array}$ & $\begin{array}{c}0.3451 * * * \\
(7.63)\end{array}$ & $\begin{array}{c}0.3214 * * * \\
(9.80)\end{array}$ & $\begin{array}{c}0.4198 * * * \\
(11.27)\end{array}$ & $\begin{array}{c}0.2426^{* * * *} \\
(6.11)\end{array}$ \\
\hline Intercept & & $\begin{array}{c}-0.2406^{* * * *} \\
(-2.96) \\
\end{array}$ & $\begin{array}{c}-0.2947 \text { **** } \\
(-3.16) \\
\end{array}$ & $\begin{array}{c}-0.3733 * * * * \\
(-3.99) \\
\end{array}$ & $\begin{array}{c}-0.5920 * * * \\
(-7.14) \\
\end{array}$ & $\begin{array}{c}-0.6080^{* * * *} \\
(-6.23)\end{array}$ & $\begin{array}{c}-0.6815^{* * * *} \\
(-7.21)\end{array}$ & $\begin{array}{c}-0.3546 * * * \\
(-4.53) \\
\end{array}$ & $\begin{array}{c}-0.3976^{* * * *} \\
(-4.32) \\
\end{array}$ & $\begin{array}{c}-0.4308 * * * * \\
(-4.71) \\
\end{array}$ \\
\hline $\begin{array}{c}\text { Country } \\
\text { FE }\end{array}$ & YES & YES & YES & YES & YES & YES & YES & YES & YES & YES \\
\hline $\begin{array}{c}\text { Industry } \\
\text { FE }\end{array}$ & YES & YES & YES & YES & YES & YES & YES & YES & YES & YES \\
\hline Year FE & YES & YES & YES & YES & YES & YES & YES & YES & YES & YES \\
\hline $\mathrm{N}$ & & 113292 & 81162 & 81054 & 114022 & 81629 & 81565 & 113290 & 81143 & 80979 \\
\hline $\mathrm{R}$-sq & & 0.239 & 0.259 & 0.254 & 0.255 & 0.277 & 0.274 & 0.255 & 0.276 & 0.274 \\
\hline Panel B & (1) & $(2)$ & (3) & (4) & $(5)$ & $(6)$ & $(7)$ & $(8)$ & (9) & $(10)$ \\
\hline $\begin{array}{c}\text { North } \\
\text { America }\end{array}$ & $\mathrm{bm}$ & $\mathrm{bm}$ & $\mathrm{bm}$ & bm & $\mathrm{bm}$ & $\mathrm{bm}$ & $\mathrm{bm}$ & $\mathrm{bm}$ & $\mathrm{bm}$ & $\mathrm{bm}$ \\
\hline col & $\begin{array}{c}-0.4433 * * * \\
(-9.67)\end{array}$ & $\begin{array}{c}-0.4495 * * * \\
(-9.32)\end{array}$ & & & $\begin{array}{c}-0.4099 * * * \\
(-8.82)\end{array}$ & & & $\begin{array}{c}-0.3208 * * * \\
(-7.02)\end{array}$ & & \\
\hline nol & $\begin{array}{c}0.0395 * * \\
(2.52)\end{array}$ & & $\begin{array}{c}0.0565^{* * * *} \\
(3.60)\end{array}$ & & & $\begin{array}{c}0.0288^{*} \\
(1.87)\end{array}$ & & & $\begin{array}{c}0.0727 * * * \\
(4.94)\end{array}$ & \\
\hline dol & $\begin{array}{c}0.0376^{* * * *} \\
(8.34)\end{array}$ & & & $\begin{array}{c}0.0346 * * * \\
(7.76)\end{array}$ & & & $\begin{array}{c}0.0281 * * * \\
(6.49)\end{array}$ & & & $\begin{array}{c}0.0317 * * * \\
(7.32)\end{array}$ \\
\hline bfl & $\begin{array}{c}0.2072 * * * \\
\quad(4.41)\end{array}$ & $\begin{array}{c}0.1510^{* * * *} \\
(3.17)\end{array}$ & $\begin{array}{c}0.2786^{* * * *} \\
(5.11)\end{array}$ & $\begin{array}{c}0.3423 * * * \\
\quad(5.40)\end{array}$ & & & & & & \\
\hline $\mathrm{mfl}$ & $\begin{array}{c}0.0926^{* * * *} \\
(18.27)\end{array}$ & & & & $\begin{array}{c}0.0845^{* * * *} \\
(15.87)\end{array}$ & $\begin{array}{c}0.0875^{* * * *} \\
(14.03)\end{array}$ & $\begin{array}{c}0.1041 * * * \\
(14.52)\end{array}$ & & & \\
\hline amfl & $\begin{array}{c}1.0335^{* * *} \\
(20.78)\end{array}$ & & & & & & & $\begin{array}{c}1.0289 * * * \\
(20.01)\end{array}$ & $\begin{array}{c}1.1349 * * * \\
(19.96)\end{array}$ & $\begin{array}{c}1.2741 * * * \\
(19.42)\end{array}$ \\
\hline Insales & & $\begin{array}{c}-0.0239 * * * \\
(-4.77)\end{array}$ & $\begin{array}{c}-0.0112^{*} \\
(-1.91)\end{array}$ & $\begin{array}{c}-0.0433 * * * \\
(-6.18)\end{array}$ & $\begin{array}{c}-0.0184 * * * \\
(-3.66)\end{array}$ & $\begin{array}{c}-0.0012 \\
(-0.21)\end{array}$ & $\begin{array}{c}-0.0324 * * * \\
(-4.78)\end{array}$ & $\begin{array}{c}-0.0314 * * * \\
(-6.42)\end{array}$ & $\begin{array}{c}-0.0198 * * * \\
(-3.47)\end{array}$ & $\begin{array}{c}-0.0510^{* * * *} \\
(-7.58)\end{array}$ \\
\hline sales_sd & & $\begin{array}{c}-0.0000^{*} \\
(-1.69)\end{array}$ & $\begin{array}{c}-0.0000 \\
(-1.41)\end{array}$ & $\begin{array}{c}0.0000 \\
(0.48)\end{array}$ & $\begin{array}{c}-0.0000^{*} \\
(-1.77)\end{array}$ & $\begin{array}{c}-0.0000 \\
(-1.55)\end{array}$ & $\begin{array}{c}-0.0000 \\
(0.23)\end{array}$ & $\begin{array}{c}-0.0000 \\
(-1.06)\end{array}$ & $\begin{array}{c}-0.0000 \\
(-0.99)\end{array}$ & $\begin{array}{c}0.0000 \\
(1.15)\end{array}$ \\
\hline nia & & $\begin{array}{c}-0.0791 * * * \\
(-6.13)\end{array}$ & $\begin{array}{c}-0.0839 * * * \\
(-6.86)\end{array}$ & $\begin{array}{c}-0.1547 * * * \\
(-4.08)\end{array}$ & $\begin{array}{c}-0.0529 * * * \\
(-5.11)\end{array}$ & $\begin{array}{c}-0.0600 * * * \\
(-5.79)\end{array}$ & $\begin{array}{c}-0.0738 * * * \\
(-2.70)\end{array}$ & $\begin{array}{c}-0.0684 * * * \\
(-6.23)\end{array}$ & $\begin{array}{c}-0.0733 * * * * \\
(-7.05)\end{array}$ & $\begin{array}{c}-0.1104 * * * \\
(-3.58)\end{array}$ \\
\hline
\end{tabular}




\begin{tabular}{|c|c|c|c|c|c|c|c|c|c|c|}
\hline Intercept & & $\begin{array}{c}0.0731 \\
(1.31) \\
0.0823 \\
(0.90) \\
\end{array}$ & $\begin{array}{c}0.0905 \\
(1.61) \\
-0.1795 * \\
(-1.81) \\
\end{array}$ & $\begin{array}{c}0.0707 \\
(0.96) \\
-0.0529 \\
(-0.46) \\
\end{array}$ & $\begin{array}{c}0.065 \\
(1.26) \\
-0.14 \\
(-1.49) \\
\end{array}$ & $\begin{array}{c}0.0673 \\
(1.22) \\
-0.3597 * * * \\
(-3.47) \\
\end{array}$ & $\begin{array}{c}0.107 \\
(1.55) \\
-0.3818 * * * \\
(-3.38) \\
\end{array}$ & $\begin{array}{c}-0.0253 \\
(-0.47) \\
-0.0609 \\
(-0.69) \\
\end{array}$ & $\begin{array}{c}0.0054 \\
(0.10) \\
-0.3166^{* * * *} \\
(-3.15) \\
\end{array}$ & $\begin{array}{c}-0.0325 \\
(-0.46) \\
-0.2535 * * \\
(-2.37) \\
\end{array}$ \\
\hline $\begin{array}{c}\text { Country } \\
\text { FE }\end{array}$ & YES & YES & YES & YES & YES & YES & YES & YES & YES & YES \\
\hline $\begin{array}{c}\text { Industry } \\
\text { FE }\end{array}$ & YES & YES & YES & YES & YES & YES & YES & YES & YES & YES \\
\hline Year FE & YES & YES & YES & YES & YES & YES & YES & YES & YES & YES \\
\hline $\mathrm{N}$ & & 41618 & 28579 & 24856 & 41907 & 28728 & 24962 & 41608 & 28572 & 24828 \\
\hline R-sq & & 0.167 & 0.16 & 0.19 & 0.192 & 0.184 & 0.223 & 0.2 & 0.204 & 0.24 \\
\hline Panel C & (1) & $(2)$ & (3) & (4) & (5) & (6) & $(7)$ & $(8)$ & $(9)$ & (10) \\
\hline Europe & $\mathrm{bm}$ & $\mathrm{bm}$ & $\mathrm{bm}$ & $\mathrm{bm}$ & bm & $\mathrm{bm}$ & $\mathrm{bm}$ & bm & $\mathrm{bm}$ & $\mathrm{bm}$ \\
\hline $\mathrm{col}$ & $\begin{array}{c}-0.4893 * * * \\
(-15.36)\end{array}$ & $\begin{array}{c}-0.4789 * * * \\
(-14.72)\end{array}$ & & & $\begin{array}{c}-0.4330 * * * \\
(-13.57)\end{array}$ & & & $\begin{array}{c}-0.3810 * * * \\
(-12.00)\end{array}$ & & \\
\hline nol & $\begin{array}{c}-0.0145 \\
(-1.34)\end{array}$ & & $\begin{array}{c}0.0247 * * \\
(2.26)\end{array}$ & & & $\begin{array}{c}-0.0118 \\
(-1.08)\end{array}$ & & & $\begin{array}{c}0.0375 * * * \\
(3.55)\end{array}$ & \\
\hline dol & $\begin{array}{c}0.0284 * * * \\
(9.80)\end{array}$ & & & $\begin{array}{c}0.0242 * * * \\
(8.47)\end{array}$ & & & $\begin{array}{c}0.0222 * * * \\
(7.84)\end{array}$ & & & $\begin{array}{c}0.0249 * * * \\
(8.83)\end{array}$ \\
\hline bfl & $\begin{array}{c}-0.0048 \\
(-0.16)\end{array}$ & $\begin{array}{c}-0.1766 * * * \\
(-5.37)\end{array}$ & $\begin{array}{c}-0.1804 * * * \\
(-4.88)\end{array}$ & $\begin{array}{c}-0.1036^{* *} \\
(-2.56)\end{array}$ & & & & & & \\
\hline $\mathrm{mfl}$ & $\begin{array}{c}0.0882 * * * \\
(26.56)\end{array}$ & & & & $\begin{array}{c}0.0769 * * * \\
(20.57)\end{array}$ & $\begin{array}{c}0.0827 * * * \\
(19.09)\end{array}$ & $\begin{array}{c}0.0889 * * * \\
(18.49)\end{array}$ & & & \\
\hline amfl & $\begin{array}{c}0.9332 * * * \\
(29.15)\end{array}$ & & & & & & & $\begin{array}{c}0.7986 * * * \\
(22.45)\end{array}$ & $\begin{array}{c}0.7764 * * * \\
(19.94)\end{array}$ & $\begin{array}{c}0.8721 * * * \\
(20.85)\end{array}$ \\
\hline Insales & & $\begin{array}{c}-0.0252 * * * \\
(-7.40)\end{array}$ & $\begin{array}{c}-0.0237 * * * \\
(-6.33)\end{array}$ & $\begin{array}{c}-0.0384 * * * \\
(-8.48)\end{array}$ & $\begin{array}{c}-0.0069 * \\
(-1.89)\end{array}$ & $\begin{array}{c}-0.0019 \\
(-0.43)\end{array}$ & $\begin{array}{c}-0.0220 * * * \\
(-4.79)\end{array}$ & $\begin{array}{c}-0.0298 * * * \\
(-8.71)\end{array}$ & $\begin{array}{c}-0.0291 * * * \\
(-7.56)\end{array}$ & $\begin{array}{c}-0.0465 * * * \\
(-10.45)\end{array}$ \\
\hline sales_sd & & $\begin{array}{c}-0.0000^{* * *} \\
(-3.15)\end{array}$ & $\begin{array}{c}-0.0000 \\
(-1.38)\end{array}$ & $\begin{array}{c}-0.0000^{* *} \\
(-2.53)\end{array}$ & $\begin{array}{c}-0.0000 * * * \\
(-3.71)\end{array}$ & $\begin{array}{c}-0.0000 \\
(-1.57)\end{array}$ & $\begin{array}{c}-0.0000 * * * \\
(-3.60)\end{array}$ & $\begin{array}{c}-0.0000 * * * \\
(-3.28)\end{array}$ & $\begin{array}{c}-0.0000 \\
(-1.39)\end{array}$ & $\begin{array}{c}-0.0000 * * * \\
(-3.08)\end{array}$ \\
\hline nia & & $\begin{array}{c}-0.0660 * * * \\
(-18.39)\end{array}$ & $\begin{array}{c}-0.0795 * * * \\
(-17.85)\end{array}$ & $\begin{array}{c}-0.0798 * * * \\
(-9.94)\end{array}$ & $\begin{array}{c}-0.0476 * * * \\
(-14.22)\end{array}$ & $\begin{array}{c}-0.0602 * * * \\
(-14.09)\end{array}$ & $\begin{array}{c}-0.0455 * * * \\
(-6.00)\end{array}$ & $\begin{array}{c}-0.0609 * * * \\
(-17.43)\end{array}$ & $\begin{array}{c}-0.0740 * * * \\
(-16.79)\end{array}$ & $\begin{array}{c}-0.0734 * * * \\
(-9.06)\end{array}$ \\
\hline tangibility & & $\begin{array}{c}0.5242^{* * *} * \\
(15.86)\end{array}$ & $\begin{array}{c}0.6203 * * * \\
(16.48)\end{array}$ & $\begin{array}{c}0.4619 * * * \\
(11.79)\end{array}$ & $\begin{array}{c}0.4380 * * * \\
(13.88)\end{array}$ & $\begin{array}{c}0.5120 * * * \\
(13.81)\end{array}$ & $\begin{array}{c}0.3451 * * * \\
(7.63)\end{array}$ & $\begin{array}{c}0.3214^{* * * *} \\
(9.80)\end{array}$ & $\begin{array}{c}0.4198 * * * \\
(11.27)\end{array}$ & $\begin{array}{c}0.2426 * * * \\
(6.11)\end{array}$ \\
\hline Intercept & & $\begin{array}{c}-0.2406 * * * \\
(-2.96) \\
\end{array}$ & $\begin{array}{c}-0.2947 * * * \\
(-3.16)\end{array}$ & $\begin{array}{c}-0.3733 * * * \\
(-3.99)\end{array}$ & $\begin{array}{c}-0.5920 * * * \\
(-7.14) \\
\end{array}$ & $\begin{array}{c}-0.6080 * * * \\
(-6.23) \\
\end{array}$ & $\begin{array}{c}-0.6815 * * * \\
(-7.21) \\
\end{array}$ & $\begin{array}{c}-0.3546 * * * \\
(-4.53) \\
\end{array}$ & $\begin{array}{c}-0.3976 * * * \\
(-4.32) \\
\end{array}$ & $\begin{array}{c}-0.4308 * * * \\
(-4.71)\end{array}$ \\
\hline $\begin{array}{c}\text { Country } \\
\text { FE }\end{array}$ & YES & YES & YES & YES & YES & YES & YES & YES & YES & YES \\
\hline $\begin{array}{c}\text { Industry } \\
\text { FE }\end{array}$ & YES & YES & YES & YES & YES & YES & YES & YES & YES & YES \\
\hline Year FE & YES & YES & YES & YES & YES & YES & YES & YES & YES & YES \\
\hline $\mathrm{N}$ & & 113292 & 81162 & 81054 & 114022 & 81629 & 81565 & 113290 & 81143 & 80979 \\
\hline R-sq & & 0.239 & 0.259 & 0.254 & 0.255 & 0.277 & 0.274 & 0.255 & 0.276 & 0.274 \\
\hline Panel D & (1) & (2) & (3) & (4) & (5) & (6) & $(7)$ & $(8)$ & $(9)$ & $(10)$ \\
\hline Asia & $\mathrm{bm}$ & $\mathrm{bm}$ & $\mathrm{bm}$ & $\mathrm{bm}$ & $\mathrm{bm}$ & $\mathrm{bm}$ & $\mathrm{bm}$ & $\mathrm{bm}$ & $\mathrm{bm}$ & $\mathrm{bm}$ \\
\hline col & $\begin{array}{c}-0.7266^{*} * * \\
(-13.64)\end{array}$ & $\begin{array}{c}-0.7191 * * * \\
(-13.32)\end{array}$ & & & $\begin{array}{c}-0.6836 * * * \\
(-12.71)\end{array}$ & & & $\begin{array}{c}-0.6755 * * * \\
(-12.51)\end{array}$ & & \\
\hline nol & $\begin{array}{c}-0.0570 * * * \\
(-3.40)\end{array}$ & & $\begin{array}{c}-0.0286^{*} \\
(-1.67)\end{array}$ & & & $\begin{array}{c}-0.0548 * * * \\
(-3.12)\end{array}$ & & & $\begin{array}{c}-0.0267 \\
(-1.57)\end{array}$ & \\
\hline dol & $\begin{array}{c}0.0207 * * * \\
(4.87)\end{array}$ & & & $\begin{array}{c}0.0199 * * * \\
(4.74)\end{array}$ & & & $\begin{array}{c}0.0191 * * * \\
(4.52)\end{array}$ & & & $\begin{array}{c}0.0203 * * * \\
(4.77)\end{array}$ \\
\hline bfl & $\begin{array}{c}-0.4178 * * * \\
(-9.11)\end{array}$ & $\begin{array}{c}-0.5739 * * * \\
(-11.95)\end{array}$ & $\begin{array}{c}-0.6524 * * * \\
(-13.10)\end{array}$ & $\begin{array}{c}-0.5055^{* * *} * \\
(-8.80)\end{array}$ & & & & & & \\
\hline $\mathrm{mfl}$ & $\begin{array}{c}0.0381 * * * \\
(7.49)\end{array}$ & & & & $\begin{array}{c}0.0362 * * * \\
(6.38)\end{array}$ & $\begin{array}{c}0.0359 * * * \\
(5.67)\end{array}$ & $\begin{array}{c}0.0594 * * * \\
(8.23)\end{array}$ & & & \\
\hline amfl & $\begin{array}{c}0.3409 * * * \\
(6.95)\end{array}$ & & & & & & & $\begin{array}{c}0.1616 * * * \\
(3.14)\end{array}$ & $\begin{array}{c}0.0986^{*} \\
(1.84)\end{array}$ & $\begin{array}{c}0.3243 * * * \\
(5.72)\end{array}$ \\
\hline Insales & & $\begin{array}{c}-0.0023 \\
(-0.54)\end{array}$ & $\begin{array}{c}0.0089 * \\
(1.88)\end{array}$ & $\begin{array}{c}-0.0482 * * * \\
(-8.53)\end{array}$ & $\begin{array}{c}0.0085 * \\
(1.65)\end{array}$ & $\begin{array}{c}0.0202 * * * \\
(3.33)\end{array}$ & $\begin{array}{c}-0.0365 * * * \\
(-5.86)\end{array}$ & $\begin{array}{c}-0.0055 \\
(-1.26)\end{array}$ & $\begin{array}{c}0.0053 \\
(1.08)\end{array}$ & $\begin{array}{c}-0.0538 * * * \\
(-9.33)\end{array}$ \\
\hline sales_sd & & $\begin{array}{c}-0.0000 \\
(-1.33)\end{array}$ & $\begin{array}{c}-0.0000 \\
(-0.82)\end{array}$ & $\begin{array}{c}-0.0000 \\
(-0.43)\end{array}$ & $\begin{array}{c}-0.0000^{*} \\
(-1.83)\end{array}$ & $\begin{array}{c}-0.0000 \\
(-0.99)\end{array}$ & $\begin{array}{c}-0.0000 * * \\
(-2.04)\end{array}$ & $\begin{array}{c}-0.0000^{*} \\
(-1.69)\end{array}$ & $\begin{array}{c}-0.0000 \\
(-0.93)\end{array}$ & $\begin{array}{c}-0.0000^{*} \\
(-1.79)\end{array}$ \\
\hline nia & & $\begin{array}{c}-0.0381 * * * \\
(-8.38)\end{array}$ & $\begin{array}{c}-0.0510 * * * \\
(-8.95)\end{array}$ & $\begin{array}{c}-0.0498 * * * \\
(-4.95)\end{array}$ & $\begin{array}{c}-0.0337 * * * \\
(-7.16)\end{array}$ & $\begin{array}{c}-0.0487 * * * \\
(-7.62)\end{array}$ & $\begin{array}{c}-0.0453 * * * \\
(-4.21)\end{array}$ & $\begin{array}{c}-0.0401 * * * \\
(-8.46)\end{array}$ & $\begin{array}{c}-0.0557 * * * \\
(-8.70)\end{array}$ & $\begin{array}{c}-0.0584 * * * \\
(-5.35)\end{array}$ \\
\hline tangibility & & $\begin{array}{c}0.4692 * * * \\
(8.34)\end{array}$ & $\begin{array}{c}0.5599 * * * \\
(9.21)\end{array}$ & $\begin{array}{c}0.3741 * * * \\
(5.63)\end{array}$ & $\begin{array}{c}0.2869 * * * \\
(5.23)\end{array}$ & $\begin{array}{c}0.3195 * * * \\
(5.32)\end{array}$ & $\begin{array}{c}0.1935 * * * \\
(3.13)\end{array}$ & $\begin{array}{c}0.2296 * * * \\
(4.02)\end{array}$ & $\begin{array}{c}0.3112 * * * \\
(5.00)\end{array}$ & $\begin{array}{c}0.1119 * \\
(1.69)\end{array}$ \\
\hline Intercept & & $\begin{array}{c}-1.4258 * * * \\
(-6.78)\end{array}$ & $\begin{array}{c}-1.2549 * * * \\
(-12.89)\end{array}$ & $\begin{array}{c}-1.0337 * * * \\
(-4.75)\end{array}$ & $\begin{array}{c}-1.6385 * * * \\
(-7.24)\end{array}$ & $\begin{array}{c}-1.4051 * * * \\
(-13.42) \\
\end{array}$ & $\begin{array}{c}-1.2228 * * * \\
(-5.05)\end{array}$ & $\begin{array}{c}-1.4893 * * * \\
(-6.68)\end{array}$ & $\begin{array}{c}-1.2727 * * * \\
(-12.86)\end{array}$ & $\begin{array}{c}-1.0370 * * * \\
(-4.28) \\
\end{array}$ \\
\hline $\begin{array}{l}\text { Country } \\
\text { FE }\end{array}$ & YES & YES & YES & YES & YES & YES & YES & YES & YES & YES \\
\hline
\end{tabular}




$\begin{array}{ccccccccrrr}\text { Industry } & \text { YES } & \text { YES } & \text { YES } & \text { YES } & \text { YES } & \text { YES } & \text { YES } & \text { YES } & \text { YES } & \text { YES } \\ \text { FE } & & \text { YES } & \text { YES } & \text { YES } & \text { YES } & \text { YES } & \text { YES } & \text { YES } & \text { YES } & \text { YES } \\ \text { Year FE } & \text { YES } & \text { YES } & 37502 & 29441 & 45040 & 37740 & 29674 & 44779 & 37496 & 29419 \\ \text { N } & & 0.434 & 0.446 & 0.395 & 0.422 & 0.429 & 0.391 & 0.42 & 0.427 & 0.387\end{array}$




\section{Table 7}

Orthogonal OLS Book-to-Market Equity Regressions

Table 7 presents OLS regressions estimating book-to-market equity (bm). Each measure of the regressed operating and financial leverage variables are orthogonalized from one another. Independent variables include: the Chen et al. measure of operating leverage (COL), the Novy-Marx measure of operating leverage (NOL), the natural log of the degree of operating leverage (DOL), book financial leverage (BFL), the natural log of market financial leverage (MFL), the alternative market financial leverage (AMFL), the natural log of sales (SALES), the rolling 5-year standard deviation of sales (SALES_SD), net income scaled by assets (NIA), tangibility measured as property, plant, and equipment scaled by assets (TANG). Additionally controlled for are industry, year, and country fixed effects. Data are from 1980 through $2016 . *, *$, and $* * *$ represent statistical significance at the $10 \%, 5 \%$, and $1 \%$ respectively. Standard errors are clustered at the firm level.

\begin{tabular}{|c|c|c|c|c|c|c|c|c|c|}
\hline & (1) & (2) & (3) & (4) & (5) & (6) & (7) & (8) & (9) \\
\hline & bm & $\mathrm{bm}$ & $\mathrm{bm}$ & $\mathrm{bm}$ & $\mathrm{bm}$ & $\mathrm{bm}$ & $\mathrm{bm}$ & $\mathrm{bm}$ & $\mathrm{bm}$ \\
\hline \multirow[t]{2}{*}{ col } & $-0.0851^{* * * *}$ & & & $-0.0892 * * *$ & & & $-0.0954 * * *$ & & \\
\hline & $(-13.96)$ & & & $(-14.83)$ & & & $(-15.99)$ & & \\
\hline \multirow[t]{2}{*}{ nol } & & $0.0189 * * *$ & & & 0.0098 & & & $0.0141^{* *}$ & \\
\hline & & (2.70) & & & (1.43) & & & (2.09) & \\
\hline \multirow[t]{2}{*}{ dol } & & & $0.0292 * * *$ & & & $0.0225^{* * *}$ & & & $0.0259^{* * * *}$ \\
\hline & & & (8.75) & & & (6.76) & & & (7.87) \\
\hline \multirow[t]{2}{*}{ bfl } & $-0.0280 * * *$ & $-0.0291 * * *$ & $-0.0162^{* *}$ & & & & & & \\
\hline & $(-5.37)$ & $(-4.88)$ & $(-2.56)$ & & & & & & \\
\hline \multirow[t]{2}{*}{$\mathrm{mfl}$} & & & & $0.1247 * * *$ & $0.1256 * * *$ & $0.1388 * * *$ & & & \\
\hline & & & & (20.57) & (19.09) & (18.49) & & & \\
\hline \multirow[t]{2}{*}{ amfl } & & & & & & & $0.1159 * * *$ & $0.1165^{* * *}$ & $0.1281^{* * *}$ \\
\hline & & & & & & & (22.45) & (19.94) & (20.85) \\
\hline Insales & $-0.0252 * * *$ & $-0.0237 * * *$ & $-0.0384 * * *$ & $-0.0069^{*}$ & -0.0019 & $-0.0220 * * *$ & $-0.0298 * * *$ & $-0.0291 * * *$ & $-0.0465 * * *$ \\
\hline
\end{tabular}




\begin{tabular}{|c|c|c|c|c|c|c|c|c|c|}
\hline & $(-7.40)$ & $(-6.33)$ & $(-8.48)$ & $(-1.89)$ & $(-0.43)$ & $(-4.79)$ & $(-8.71)$ & $(-7.56)$ & $(-10.45)$ \\
\hline \multirow[t]{2}{*}{ nia } & $-0.0660 * * *$ & $-0.0795 * * *$ & $-0.0798 * * *$ & $-0.0476 * * *$ & $-0.0602 * * *$ & $-0.0455 * * *$ & $-0.0609 * * *$ & $-0.0740 * * *$ & $-0.0734 * * *$ \\
\hline & $(-18.39)$ & $(-17.85)$ & $(-9.94)$ & $(-14.22)$ & $(-14.09)$ & $(-6.00)$ & $(-17.43)$ & $(-16.79)$ & $(-9.06)$ \\
\hline \multirow[t]{2}{*}{ tangibility } & $0.5242 * * *$ & $0.6203 * * *$ & $0.4619 * * *$ & $0.4380 * * *$ & $0.5120 * * *$ & $0.3451^{* * *}$ & $0.3214 * * *$ & $0.4198 * * *$ & $0.2426 * * *$ \\
\hline & (15.86) & (16.48) & (11.79) & (13.88) & (13.81) & (7.63) & $(9.80)$ & (11.27) & $(6.11)$ \\
\hline \multirow[t]{2}{*}{ sales_sd } & $-0.0000 * * *$ & 0 & $-0.0000 * *$ & $-0.0000 * * *$ & 0 & $-0.0000 * * *$ & $-0.0000 * * *$ & 0 & $-0.0000^{* * * *}$ \\
\hline & $(-3.15)$ & $(-1.38)$ & $(-2.53)$ & $(-3.71)$ & $(-1.57)$ & $(-3.60)$ & $(-3.28)$ & $(-1.39)$ & $(-3.08)$ \\
\hline \multirow[t]{2}{*}{ Intercept } & $-0.3932 * * *$ & $-0.3028 * * *$ & $-0.3990 * * *$ & $-0.6911 * * *$ & $-0.6158 * * *$ & $-0.6662 * * *$ & $-0.3156^{* * *}$ & $-0.2248 * *$ & $-0.2786 * * *$ \\
\hline & $(-4.91)$ & $(-3.28)$ & $(-4.25)$ & $(-8.45)$ & $(-6.31)$ & $(-7.06)$ & $(-4.09)$ & $(-2.46)$ & $(-3.05)$ \\
\hline $\begin{array}{c}\text { Country } \\
\text { FE }\end{array}$ & YES & YES & YES & YES & YES & YES & YES & YES & YES \\
\hline $\begin{array}{c}\text { Industry } \\
\text { FE }\end{array}$ & YES & YES & YES & YES & YES & YES & YES & YES & YES \\
\hline Year FE & YES & YES & YES & YES & YES & YES & YES & YES & YES \\
\hline $\mathrm{N}$ & 113292 & 81162 & 81054 & 114022 & 81629 & 81565 & 113290 & 81143 & 80979 \\
\hline R-sq & 0.239 & 0.259 & 0.254 & 0.255 & 0.277 & 0.274 & 0.255 & 0.276 & 0.274 \\
\hline
\end{tabular}




\section{Table 8}

Fama-French Time-Series BMP

Table 8 presents estimates of the book-to-market equity premium (BMP), measured as the difference of the top tercile from the bottom tercile. Panel A presents equal-weighted factors and Panel B presents value-weighted factors. Independent variables are factors created across the Chen et al. measure of operating leverage (COLP), the Novy-Marx measure of operating leverage (NOLP), the natural log of the degree of operating leverage (DOLP), book financial leverage (BFLP), the natural log of market financial leverage (MFLP), the alternative market financial leverage (AMFLP), the market risk premium (MKT), and the size premium (SP), and country fixed effects. Portfolios are rebalanced each June. Data are from 1980 through 2016. *, **, and *** represent statistical significance at the $10 \%, 5 \%$, and $1 \%$ respectively.

\begin{tabular}{|c|c|c|c|c|c|c|c|c|c|c|}
\hline Panel A & (1) & (2) & (3) & (4) & (5) & (6) & (7) & (8) & (9) & (10) \\
\hline Equal Weighted & BMP & BMP & BMP & BMP & BMP & BMP & BMP & BMP & BMP & BMP \\
\hline \multirow[t]{2}{*}{ COLP } & $-0.1067 * * *$ & $-0.0967 * * *$ & & & $-0.0900^{* * * *}$ & & & $-0.0862 * * * *$ & & \\
\hline & $(-10.09)$ & $(-8.97)$ & & & $(-8.53)$ & & & $(-8.17)$ & & \\
\hline \multirow[t]{2}{*}{ NOLP } & $-0.0575 * * *$ & & $-0.0773 * * *$ & & & $-0.0818 * * *$ & & & $-0.0765 * * *$ & \\
\hline & $(-5.51)$ & & $(-7.36)$ & & & $(-8.09)$ & & & $(-7.56)$ & \\
\hline \multirow[t]{2}{*}{ DOLP } & $0.0612 * * *$ & & & $0.0272 * *$ & & & $0.0279 * *$ & & & $0.0246 * *$ \\
\hline & (5.17) & & & $(2.24)$ & & & $(2.34)$ & & & $(2.08)$ \\
\hline \multirow[t]{2}{*}{ BFLP } & $0.0910 * * *$ & $0.1504 * * *$ & $0.1897 * * *$ & $0.1359 * * *$ & & & & & & \\
\hline & (6.99) & $(9.85)$ & (11.63) & $(9.23)$ & & & & & & \\
\hline \multirow[t]{2}{*}{ MFLP } & $0.2673 * * *$ & & & & $0.2385^{* * * *}$ & $0.3034 * * *$ & $0.2644 * * *$ & & & \\
\hline & (21.46) & & & & (16.38) & (19.83) & (19.13) & & & \\
\hline \multirow[t]{2}{*}{ AMFLP } & $0.3104 * * *$ & & & & & & & $0.2906^{* * *}$ & $0.3476^{* * *}$ & $0.3154 * * *$ \\
\hline & $(23.60)$ & & & & & & & (19.27) & $(21.82)$ & $(21.81)$ \\
\hline \multirow[t]{2}{*}{ MKT } & & $0.0611 * * *$ & $0.0772 * * *$ & $0.0717 * * *$ & $0.0558 * * *$ & $0.0734 * * *$ & $0.0668^{* * * *}$ & $0.0529 * * *$ & $0.0704 * * *$ & $0.0601 * * *$ \\
\hline & & (7.66) & $(9.38)$ & $(9.22)$ & (7.19) & $(9.30)$ & $(8.81)$ & $(6.87)$ & $(8.97)$ & (7.98) \\
\hline \multirow[t]{2}{*}{ SP } & & $-0.1928 * * *$ & $-0.2230 * * *$ & $-0.2019 * * *$ & $-0.1485^{* * *}$ & $-0.1642 * * *$ & $-0.1554 * * *$ & $-0.1557 * * *$ & $-0.1752 * * *$ & $-0.1644 * * *$ \\
\hline & & $(-16.07)$ & $(-17.48)$ & $(-17.14)$ & $(-12.47)$ & $(-13.27)$ & $(-13.46)$ & $(-13.14)$ & $(-14.21)$ & $(-14.31)$ \\
\hline
\end{tabular}




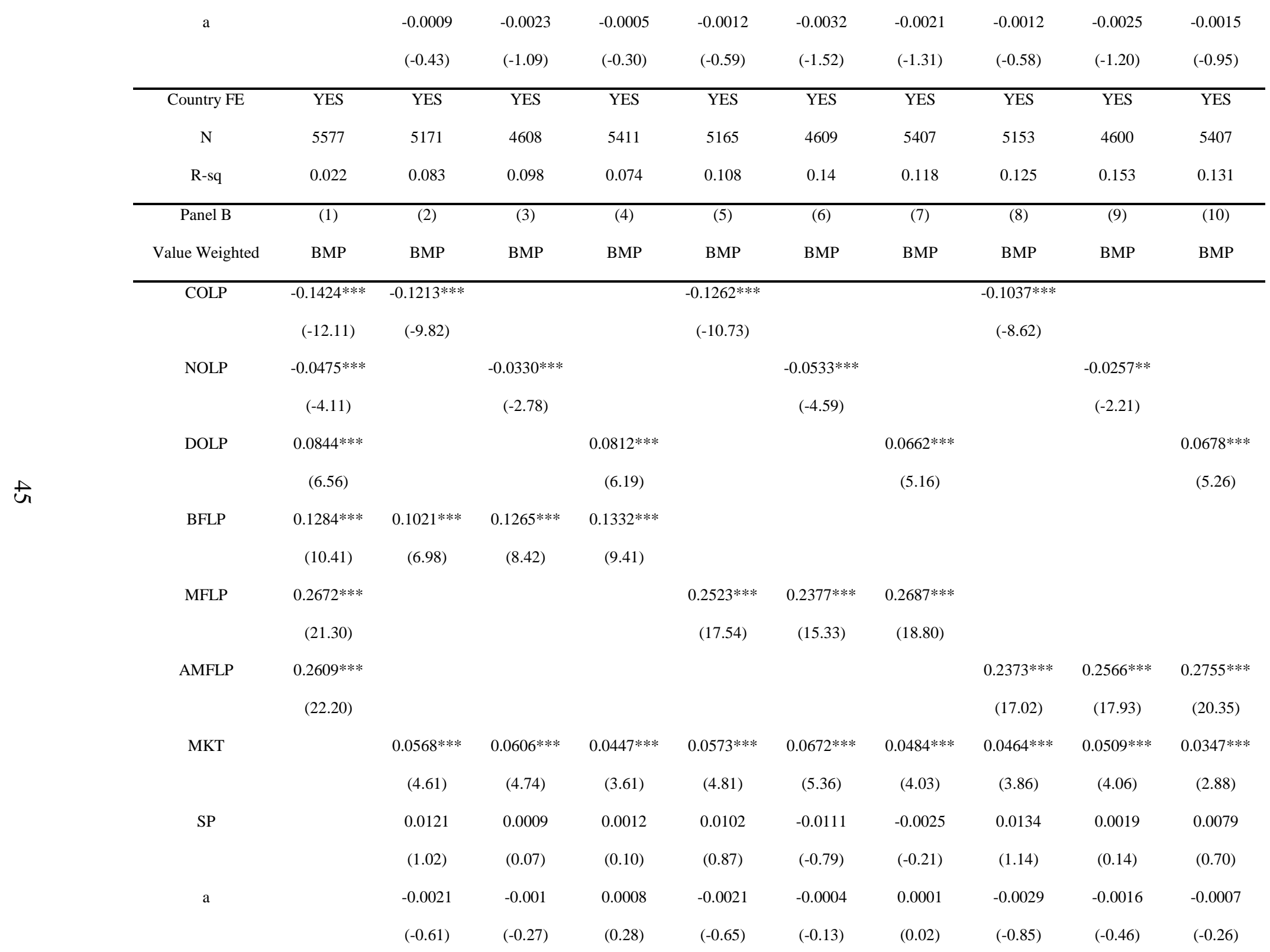




\begin{tabular}{cccccccccccc}
\hline Country FE & YES & YES & YES & YES & YES & YES & YES & YES & YES & YES \\
N & 5590 & 5165 & 4618 & 5390 & 5144 & 4617 & 5375 & 5171 & 4633 & 5390 \\
R-sq & 0.029 & 0.042 & 0.026 & 0.029 & 0.085 & 0.06 & 0.074 & 0.087 & 0.075 & 0.084
\end{tabular}




\section{Table 9}

Employment Protection and Operating Leverage

Table 9 presents difference-in-differences estimates of the effect of EPL reforms on OL. Panel A presents all three OL measures, and Panel B presents the forward DOL estimates. The dependent variables are the Chen et al. measure of operating leverage (COL), the Novy-Marx measure of operating leverage (NOL), the natural log of the degree of operating leverage (DOL). EPL -/+ $\mathrm{i}$ is a dummy equal to 1 if the year of the deal is the ith year before (after) the employment reform and zero otherwise. Controls include the natural log of sales (SALES), the rolling 5-year standard deviation of sales (SALES_SD), as well as country, industry, and year fixed effects. Data are from 1985 through $2007 . * * *$, and $* * *$ represent statistical significance at the $10 \%, 5 \%$, and $1 \%$ respectively.

\begin{tabular}{|c|c|c|c|c|c|c|}
\hline Panel A & (1) & (2) & (3) & (4) & (5) & (6) \\
\hline $\mathrm{OL}$ & $\mathrm{COL}$ & NOL & DOL & $\mathrm{COL}$ & NOL & DOL \\
\hline \multirow[t]{2}{*}{$\begin{array}{l}\text { EPL-2 } \\
\end{array}$} & $0.0163^{* * * *}$ & -0.0293 & $0.0714^{*}$ & 0.0076 & -0.0023 & 0.0347 \\
\hline & (3.18) & $(-1.37)$ & (1.93) & (1.38) & $(-0.10)$ & (1.01) \\
\hline \multirow[t]{2}{*}{ EPL-1 } & $0.0173 * * *$ & 0.0291 & -0.0191 & $0.0106^{* *}$ & $0.0385^{*}$ & $-0.0691 * *$ \\
\hline & (3.48) & (1.44) & $(-0.54)$ & (2.01) & (1.79) & $(-2.15)$ \\
\hline \multirow[t]{2}{*}{ EPLO } & $0.0155 * * *$ & $0.0306^{*}$ & $-0.1257 * * *$ & $0.0080^{*}$ & $0.0348 *$ & $-0.1859 * * *$ \\
\hline & (3.46) & (1.67) & $(-3.58)$ & (1.70) & (1.84) & $(-5.89)$ \\
\hline \multirow[t]{2}{*}{ EPL+1 } & $0.0137 * * *$ & $0.0510 * * *$ & $-0.1806 * * *$ & $0.0093 * *$ & $0.0579 * * *$ & $-0.2318^{* * * *}$ \\
\hline & $(3.22)$ & (2.90) & $(-5.43)$ & (2.10) & (3.18) & $(-7.77)$ \\
\hline \multirow[t]{2}{*}{ EPL+2 } & $0.0161 * * *$ & $0.0359 * *$ & $-0.1939 * * *$ & $0.0117 * * *$ & $0.0512 * * *$ & $-0.2222 * * *$ \\
\hline & (3.88) & (2.15) & $(-5.77)$ & (2.69) & $(3.00)$ & $(-7.29)$ \\
\hline \multirow[t]{2}{*}{ EPL+3 } & $0.0126 * * *$ & $0.0410^{* *}$ & $-0.0595 *$ & $0.0104 * *$ & $0.0544 * * *$ & $-0.0577 *$ \\
\hline & (3.17) & (2.51) & $(-1.71)$ & (2.49) & $(3.26)$ & $(-1.84)$ \\
\hline \multirow[t]{2}{*}{ EPL+4 } & $0.0091 * *$ & $0.0382^{* *}$ & -0.0431 & $0.0095 * *$ & $0.0491 * * *$ & -0.0477 \\
\hline & (2.40) & (2.36) & $(-1.25)$ & (2.39) & (2.96) & $(-1.54)$ \\
\hline \multirow[t]{2}{*}{ SALES } & & & & $0.0032 * * *$ & $0.0553 * * *$ & $0.5930 * * *$ \\
\hline & & & & (3.68) & (15.06) & (66.68) \\
\hline \multirow[t]{2}{*}{ SALES_SD } & & & & $-0.0110^{* * * *}$ & $-0.0354 * * *$ & $-0.6433 * * *$ \\
\hline & & & & $(-13.40)$ & $(-10.69)$ & $(-77.27)$ \\
\hline \multirow[t]{2}{*}{ Intercept } & $0.1595 * * *$ & $1.0099 * * *$ & $-0.3959 * * *$ & $0.2395 * * *$ & $0.6980 * * *$ & $-0.8660 * * *$ \\
\hline & (14.14) & (21.41) & $(-5.68)$ & (18.79) & (13.89) & $(-11.37)$ \\
\hline Country FE & YES & YES & YES & YES & YES & YES \\
\hline Industry FE & YES & YES & YES & YES & YES & YES \\
\hline Year FE & YES & YES & YES & YES & YES & YES \\
\hline $\mathrm{N}$ & 85386 & 68853 & 63802 & 77139 & 63258 & 62453 \\
\hline R-sq & 0.326 & 0.294 & 0.08 & 0.339 & 0.303 & 0.2 \\
\hline
\end{tabular}

\begin{tabular}{|c|c|c|c|c|c|c|c|c|c|c|c|c|}
\hline Panel B & (1) & (2) & (3) & (4) & (5) & (6) & (7) & (8) & (9) & (10) & (11) & (12) \\
\hline DOL & DOL & DOL+1 & $\mathrm{DOL}+2$ & $\mathrm{DOL}+3$ & DOL+4 & DOL +5 & DOL & DOL+1 & $\mathrm{DOL}+2$ & DOL+3 & DOL+4 & $\mathrm{DOL}+5$ \\
\hline EPL-2 & $0.0714 *$ & -0.0239 & $-0.1401 * * *$ & -0.1436 *** & $-0.0834 * *$ & 0.0352 & 0.0347 & -0.0518 & $-0.1505^{* * * *}$ & $-0.1490 * * *$ & $-0.0882 * *$ & 0.04 \\
\hline
\end{tabular}




\begin{tabular}{|c|c|c|c|c|c|c|c|c|c|c|c|c|}
\hline & $(1.93)$ & $(-0.69)$ & $(-3.96)$ & $(-4.24)$ & $(-2.43)$ & $(0.99)$ & $(1.01)$ & $(-1.56)$ & $(-4.32)$ & $(-4.41)$ & $(-2.52)$ & (1.06) \\
\hline \multirow[t]{2}{*}{ EPL-1 } & -0.0191 & $-0.1456 * * *$ & $-0.1923 * * *$ & $-0.1419 * * *$ & -0.0001 & -0.0196 & $-0.0691 * *$ & $-0.1836^{* * *}$ & $-0.2076^{* * *}$ & $-0.1458 * * *$ & 0.009 & 0.0004 \\
\hline & $(-0.54)$ & $(-4.06)$ & $(-5.66)$ & $(-4.16)$ & $(-0.00)$ & $(-0.56)$ & $(-2.15)$ & $(-5.47)$ & $(-6.28)$ & $(-4.26)$ & $(0.25)$ & $(0.01)$ \\
\hline \multirow[t]{2}{*}{ EPL0 } & $-0.1257 * * *$ & $-0.1759 * * *$ & $-0.1443^{* * *}$ & -0.0279 & -0.0326 & -0.0311 & $-0.1859 * * *$ & $-0.2234 * * *$ & $-0.1756^{* * *}$ & -0.0389 & -0.0442 & -0.0302 \\
\hline & $(-3.58)$ & $(-5.27)$ & $(-4.32)$ & $(-0.82)$ & $(-0.96)$ & $(-0.90)$ & $(-5.89)$ & $(-7.11)$ & $(-5.38)$ & $(-1.14)$ & $(-1.27)$ & $(-0.82)$ \\
\hline \multirow[t]{2}{*}{$\mathrm{EPL}+1$} & $-0.1806 * * *$ & $-0.1602 * * *$ & -0.0298 & -0.0283 & -0.035 & $0.0755^{* *}$ & $-0.2318 * * *$ & $-0.1872 * * *$ & -0.0523 & -0.0281 & -0.0151 & $0.1012 * * *$ \\
\hline & $(-5.43)$ & $(-4.80)$ & $(-0.87)$ & $(-0.84)$ & $(-1.04)$ & $(2.37)$ & $(-7.77)$ & $(-6.01)$ & $(-1.56)$ & $(-0.82)$ & $(-0.44)$ & $(3.01)$ \\
\hline \multirow[t]{2}{*}{$\mathrm{EPL}+2$} & $-0.1939 * * *$ & -0.0564 & $-0.0672 * *$ & $-0.0664 * *$ & 0.0288 & $0.0998 * * *$ & $-0.2222 * * *$ & $-0.0829 * *$ & $-0.0734 * *$ & $-0.0605 *$ & 0.0412 & $0.1255^{* * * *}$ \\
\hline & $(-5.77)$ & $(-1.64)$ & $(-1.99)$ & $(-1.99)$ & $(0.91)$ & $(3.27)$ & $(-7.29)$ & $(-2.55)$ & $(-2.20)$ & $(-1.80)$ & $(1.27)$ & $(3.88)$ \\
\hline \multirow[t]{2}{*}{$\mathrm{EPL}+3$} & $-0.0595 *$ & $-0.0613^{*}$ & -0.0508 & 0.0147 & $0.0779 * *$ & $0.1133 * * *$ & $-0.0577^{*}$ & $-0.0592 *$ & -0.045 & 0.0268 & $0.0943 * * *$ & $0.1240 * * *$ \\
\hline & $(-1.71)$ & $(-1.80)$ & $(-1.51)$ & $(0.46)$ & $(2.57)$ & $(3.79)$ & $(-1.84)$ & $(-1.83)$ & $(-1.36)$ & $(0.85)$ & (3.07) & $(3.92)$ \\
\hline \multirow[t]{2}{*}{$\mathrm{EPL}+4$} & -0.0431 & -0.0412 & -0.0038 & $0.0681 * *$ & $0.0965 * * *$ & 0.0333 & -0.0477 & -0.0446 & -0.002 & $0.0810^{* * * *}$ & $0.0971 * * *$ & $0.0568^{*}$ \\
\hline & $(-1.25)$ & $(-1.21)$ & $(-0.12)$ & $(2.28)$ & $(3.33)$ & $(1.08)$ & $(-1.54)$ & $(-1.40)$ & $(-0.07)$ & $(2.72)$ & (3.30) & $(1.76)$ \\
\hline \multirow[t]{2}{*}{ SALES } & & & & & & & $0.5930 * * *$ & $0.5112 * * *$ & $0.3674 * * *$ & $0.2322 * * *$ & $0.1274 * * *$ & $0.1115^{* * *}$ \\
\hline & & & & & & & $(66.68)$ & $(58.30)$ & $(43.64)$ & $(28.45)$ & (16.48) & (13.79) \\
\hline \multirow[t]{2}{*}{ SALES_SD } & & & & & & & $-0.6433 * * *$ & $-0.5459 * * *$ & $-0.3796^{* * *}$ & $-0.2158 * * *$ & $-0.0865 * * *$ & $-0.0677 * * *$ \\
\hline & & & & & & & $(-77.27)$ & $(-65.84)$ & $(-47.70)$ & $(-28.32)$ & $(-12.37)$ & $(-9.33)$ \\
\hline \multirow[t]{2}{*}{ Intercept } & $-0.3959 * * *$ & $-0.3096 * * *$ & $-0.3328 * * *$ & $-0.2750 * * *$ & $-0.2120 * * *$ & $-0.1644 * *$ & $-0.8660 * * *$ & $-0.8333 * * *$ & $-0.8671 * * *$ & $-0.8981 * * *$ & $-0.9021 * * *$ & $-0.8494 * * *$ \\
\hline & $(-5.68)$ & $(-4.61)$ & $(-4.87)$ & $(-4.05)$ & $(-3.12)$ & $(-2.37)$ & $(-11.37)$ & $(-11.05)$ & $(-11.14)$ & $(-11.32)$ & $(-11.16)$ & $(-9.92)$ \\
\hline Country FE & YES & YES & YES & YES & YES & YES & YES & YES & YES & YES & YES & YES \\
\hline Industry FE & YES & YES & YES & YES & YES & YES & YES & YES & YES & YES & YES & YES \\
\hline Year FE & YES & YES & YES & YES & YES & YES & YES & YES & YES & YES & YES & YES \\
\hline $\mathrm{N}$ & 63802 & 62634 & 61318 & 59659 & 57341 & 53732 & 62453 & 61358 & 59897 & 57814 & 54651 & 47821 \\
\hline R-sq & 0.08 & 0.079 & 0.079 & 0.079 & 0.079 & 0.08 & 0.2 & 0.166 & 0.122 & 0.095 & 0.087 & 0.09 \\
\hline
\end{tabular}

